OPEN ACCESS

Edited by:

Levente Bodrossy,

Oceans and Atmosphere (CSIRO),

Australia

Reviewed by:

Ronald Oremland,

United States Geological Survey

(USGS), United States

Melanie R. Mormile,

Missouri University of Science

and Technology, United States

*Correspondence:

Alexander S. Savvichev savvichev@mail.ru

Specialty section:

This article was submitted to

Aquatic Microbiology,

a section of the journal

Frontiers in Microbiology

Received: 20 May 2020

Accepted: 23 July 2020

Published: 11 August 2020

Citation:

Savvichev AS, Kadnikov W, Rusanov II, Beletsky AV, Krasnova ED, Voronov DA, Kallistova AY, Veslopolova EF, Zakharova EE, Kokryatskaya NM, Losyuk GN,

Demidenko NA, Belyaev NA,

Sigalevich PA, Mardanov AV, Ravin NV and Pimenov NV (2020) Microbial Processes and Microbial Communities in the Water Column of the Polar Meromictic Lake Bol'shie Khruslomeny at the White Sea Coast.

Front. Microbiol. 11:1945. doi: 10.3389/fmicb.2020.01945

\section{Microbial Processes and Microbial Communities in the Water Column of the Polar Meromictic Lake Bol'shie Khruslomeny at the White Sea Coast}

\author{
Alexander S. Savvichev ${ }^{1 *}$, Vitaly V. Kadnikov'2, Igor I. Rusanov', Alexey V. Beletsky ${ }^{2}$, \\ Elena D. Krasnova ${ }^{3}$, Dmitry A. Voronov ${ }^{3}$, Anna Yu. Kallistova', Elena F. Veslopolova', \\ Elena E. Zakharova ${ }^{1}$, Nataliya M. Kokryatskaya $^{4}$, Galina N. Losyuk ${ }^{4}$, \\ Nikolai A. Demidenko ${ }^{5}$, Nikolai A. Belyaev6, Pavel A. Sigalevich ${ }^{1}$, Andrey V. Mardanov², \\ Nikolai V. Ravin ${ }^{2}$ and Nikolay V. Pimenov \\ 'Winogradsky Institute of Microbiology, Research Center of Biotechnology, Russian Academy of Sciences, Moscow, Russia, \\ ${ }^{2}$ Institute of Bioengineering, Research Center of Biotechnology, Russian Academy of Sciences, Moscow, Russia, ${ }^{3}$ Faculty \\ of Biology, Lomonosov Moscow State University, Moscow, Russia, ${ }^{4}$ N. Laverov Federal Center for Integrated Arctic \\ Research, Ural Branch, Russian Academy of Sciences, Moscow, Russia, ${ }^{5}$ Zubov State Oceanographic Institute, Moscow, \\ Russia, ${ }^{6}$ Shirshov Institute of Oceanology, Russian Academy of Sciences, Moscow, Russia
}

Microbiological, molecular ecological, biogeochemical, and isotope geochemical research was carried out at the polar Lake Bol'shie Khruslomeny at the coast of the Kandalaksha Bay, White Sea in March and September 2017. The uppermost mixolimnion was oxic, with low salinity (3-5\%). The lower chemocline layer was browngreen colored, with very high content of particulate organic matter (up to $11.8 \mathrm{mg}$ $\left.C L^{-1}\right)$. The lowermost monimolimnion had marine salinity (22-24\%) and very high concentrations of sulfide (up to $18 \mathrm{mmol} \mathrm{L}^{-1}$ ) and $\mathrm{CH}_{4}$ (up to $1.8 \mathrm{mmol} \mathrm{L}^{-1}$ ). In the chemocline, total microbial abundance and the rate of anoxygenic photosynthesis were $8.8 \times 10^{6}$ cells $\mathrm{mL}^{-1}$ and $34.4 \mu \mathrm{mol} \mathrm{CL^{-1 }}$ day ${ }^{-1}$, respectively. Both in March and September, sulfate reduction rate increased with depth, peaking (up to

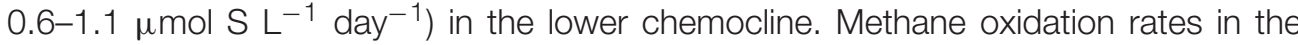
chemocline were up to 85 and $180 \mathrm{nmol} \mathrm{CH}_{4} \mathrm{~L}^{-1}$ day $^{-1}$ in March and September, respectively; stimulation of this process by light was observed in September. The percentages of cyanobacteria and methanotrophs in the layer where light-induced methane oxidation occurred were similar, $\sim 2.5 \%$ of the microbial community. Light did not stimulate methane oxidation in deeper layers. The carbon isotope composition of particulate organic matter $\left(\delta^{13} \mathrm{C}\right.$-Corg), dissolved carbonates $\left(\delta^{13} \mathrm{C}-\mathrm{DIC}\right)$, and methane $\left(\delta^{13} \mathrm{C}-\mathrm{CH}_{4}\right)$ indicated high microbial activity in the chemocline. Analysis of the $16 \mathrm{~S}$ rRNA gene sequences revealed predominance of Cyanobium cyanobacteria (order Synechococcales) in the mixolimnion. Green sulfur bacteria Chlorobium phaeovibrioides capable of anoxygenic photosynthesis constituted $\sim 20 \%$ of the chemocline community both in March and in September. Methyloprofundus gammaptoteobacteria (family Methylomonaceae) were present in the upper chemocline, where active methane oxidation occurred. During winter, cyanobacteria were less abundant in the chemocline, while methanotrophs occurred in higher horizons, including the under-ice layer. Chemolithotrophic gammaproteobacteria of the genus Thiomicrorhabdus, oxidizing 
reduced sulfur compounds at low oxygen concentrations, were revealed in the chemocline in March. Both in March and September archaea constituted up to 50\% of all microorganisms in the hypolimnion. The percentage of putative methanogens in the archaeal community was low, and they occurred mainly in near-bottom horizons.

Keywords: carbon cycle, sulfur cycle, meromictic lakes, microbial communities, White Sea, anoxygenic phototrophic bacteria, Chlorobium, carbon isotope fractionation

\section{INTRODUCTION}

Meromictic (permanently stratified) lakes are formations in which microbial geochemical activity is most pronounced (Overmann et al., 1991; Crowe et al., 2014; Walter et al., 2014). The highest rates of microbial processes occur in the zone where oxic and anoxic (euxinic, oxygen-free, sulfide-enriched) water layers contact. This zone is termed a chemocline (Overmann et al., 1991), pycnocline (Galand et al., 2012), a transitory zone (Schmidtova et al., 2009), or an oxic-anoxic interface (Vetriani et al., 2003). Among the natural compounds acting as oxidizers, oxygen is the most energetically advantageous electron acceptor for heterotrophic organisms consuming organic matter (Wang and Van Cappellen, 1996). Microorganisms oxidize reduced sulfur, iron, and manganese compounds (Canfield et al., 1993), as well as methane (Eller et al., 2005), primarily using oxygen. Oxygen respiration of heterotrophic and chemolithotrophic microorganisms may occur at very low ambient oxygen levels, which are below $120 \mathrm{nM}$, the threshold for conventional oxygen sensors (Stolper et al., 2010). The processes occurring at micromolar oxygen concentrations have not been studied until recently (Brand et al., 2016).

Prokaryotes are known to be the only organisms capable of methane oxidation in aquatic ecosystems under both oxic and anoxic conditions (Reeburgh, 2007; Bastviken et al., 2008). In the absence of oxygen and presence of sulfate, methane is consumed mainly due to sulfate-dependent anaerobic methane oxidation (AOM), which is responsible for the oxidation of over $90 \%$ methane in anoxic zones of marine environments (Strous and Jetten, 2004; Knittel and Boetius, 2009). In the water column of meromictic lakes, microbial methane oxidation is known to occur, apart from the oxic zone, also at the oxicanoxic interface (Schubert et al., 2010), as well as in the anoxic zone, where oxygen can not be detected (Blees et al., 2014; Milucka et al., 2015). Light was shown to stimulate methane oxidation in anoxic lake water (Milucka et al., 2015; Oswald et al., 2015; Kallistova et al., 2018). This may indicate that oxygen used by methanotrophs for methane oxidation may be produced via oxygenic photosynthesis. While the minimum light requirement for oxygenic phototrophs is considered to be $\sim 2 \mu \mathrm{Em}^{-2} \mathrm{~s}^{-1}$ (Raven et al., 2000), it may in fact be significantly lower. Gibson (1985) reported the minimal photon flow of 0.1 to $0.5 \mu \mathrm{E} \mathrm{m} \mathrm{m}^{-2} \mathrm{~s}^{-1}$ for freshwater and $0.02 \mu \mathrm{E} \mathrm{m} \mathrm{m}^{-2} \mathrm{~s}^{-1}$ for marine environments. Moreover, anoxygenic phototrophs, e.g., Chlorobiaceae, may carry out anoxygenic photosynthesis at illumination levels below $0.01 \mu \mathrm{Em}^{-2} \mathrm{~s}^{-1}$ (Raven et al., 2000).

In the chemocline zone of meromictic lakes, a complex multilayer microbial community develops, which carries out conversion of carbon, sulfur, iron, and manganese compounds (Kuznetsov, 1970; Ivanov et al., 2001; Pimenov et al., 2003; Savvichev et al., 2004, 2018; Wand et al., 2006; Crowe et al., 2010; Rogozin et al., 2010, 2017; Galand et al., 2012).

Meromictic lakes may act as models for investigation of microbial biogeochemical processes occurring at the oxic-anoxic interface (Koeksoy et al., 2016; Lambrecht et al., 2019). Moreover, investigation of the composition and function of microbial communities involved in the methane biogeochemical cycle is also important for the understanding of climatic changes (Singh et al., 2010; Boetius, 2019). Among diverse meromictic basins, those located in coastal areas and to some extent connected to the sea (constantly of periocically) are of special interest. Several lakes of such type at the Cape Kindo coast (Kandalaksha Bay, White Sea) have recently attracted attention of researchers: Lakes KisloSladkoe, Trekhtsvetnoe, and Elovoe. The coastal stratified lakes of the Kandalaksha shore, White Sea, are unique in origin and have very young age. They developed due to gradual separation from the sea caused by rapid rising of the land $(\sim 40 \mathrm{~cm}$ in the last 100 years), which started with deglaciation and is presently going on (Krasnova et al., 2015). Moreover, this area is characterized by highly indented coastline and abundance of islands (Krasnova et al., 2015). In the course of land rising and separation of these bays from the sea, the upper water layer becomes desalinated, and marine biota is replaced by the freshwater one. Applied value of research on microbial communities and microbial processes in the basins separated from the major sea basin stems from the necessity to predict the possibility of sulfide contamination in artificially closed sea areas resulting from construction of dams, piers, tidal power stations, etc. (Velinsky and Fogel, 1999; Savvichev et al., 2017).

Investigation of these basins revealed a pronounced peak of light $\tilde{N}_{2}$ fixation in the chemocline zone, which was associated with activity of anoxygenic phototrophic bacteria (Savvichev et al., 2014). Predominant organisms in this layer were greencolored green sulfur bacteria (GSB) Chlorobium chlorovibrioides, while brown-colored GSB Chlorobium phaeovibrioides, as well as purple sulfur bacteria Thiocapsa rosea and Thiorhodococcus kakinadensis and non-sulfur purple bacteria Rhodovulum sulfidophilum, predominated in the lower horizon (Lunina et al., 2013). The pronounced red layer in the chemocline of Lake KisloSladkoe was shown to contain high numbers of cryptophyte algae of the genus Rhodomonas (Cryptophyta, Pirenomonadaceae) (Krasnova et al., 2014). These basins are characterized by intense sulfate reduction in the chemocline and hypolimnion, as well as by involvement of photo- and chemoautotrophic bacteria in production of organic matter with unusual carbon isotope composition (Savvichev et al., 2014). The patterns of 
microbial processes in meromictic lakes depend significantly on their topographic location and genesis. The composition and functional activity of microbial communities depend on a number of parameters: temperature, salt composition, trophic status, depth of light penetration, etc.

Lake Bol'shie Khruslomeny ( $\left.66^{\circ} 42^{\prime} 59^{\prime \prime} \mathrm{N}, 32^{\circ} 51^{\prime} 30^{\prime \prime} \mathrm{E}\right)$ is a meromictic basin of marine genesis. This small lake with indented coastline and the highest depth of $18.5 \mathrm{~m}$ is located on Olenii Island (Kandalaksha Bay, White Sea at the latitude of the Polar circle, $23 \mathrm{~km}$ from the White Sea Biological Station (WSBS) of the Moscow State University (Krasnova et al., 2015). The upper $2 \mathrm{~m}$ layer with low salinity is subject to wind mixing; salinity of the lower layers is higher. Seawater penetrates into the lake via a boulder dam in its southern part during syzygy tides and especially strong winds. Only $\sim 100$ years ago, this lake was a regular sea gulf. A stratified water column developed during this short period of isolation from the sea. This evolution resulted in changes in the composition of the microbial community and in the scale of microbial processes. Establishing the present-day state of the microbial community and microbial processes in this rapidly evolving basin was the goal of the present work.

The goal of the present work was to determine the parameters of the microbial community in the water column of the meromictic Lake B. Khruslomeny using molecular genetic approaches, as well as the rates of microbial processes (autotrophic and heterotrophic $\mathrm{CO}_{2}$ fixation, sulfate reduction, methanogenesis, and methane oxidation), and to determine the carbon isotope composition of particulate organic matter, dissolved methane, and bicarbonate.

\section{MATERIALS AND METHODS}

\section{Sampling}

The work at the lake B. Khruslomeny (Figure 1) was carried out in March and September, 2017.

Water samples were collected at the point of the greatest depth $(18.5 \mathrm{~m})$. The samples were taken from various depths using a silicon rubber tube attached to a gaged line and a GP1352 Whale Premium Submersible Pump (Ireland). The samples were dispensed into $30-\mathrm{mL}$ glass vials, sealed with gastight rubber stoppers avoiding air bubbles, and closed with perforated aluminum caps.

Illuminance was measured with an AR813A Luxmeter (China), with the registering unit modified for underwater use and mounted on a gaged cable line. The temperature and concentration of dissolved oxygen were measured with a WTW ${ }^{\odot}$ 340iA HANNA HI8314F (Wensoket, RI, United States) portable ionometer with temperature compensation; a combination electrode was used for $\mathrm{pH}$ measurement. Specific conductivity was determined with a HANNA HI8733 (Wensoket, RI, United States) portable conductometer.

Methane concentration in the water samples was determined by the headspace method (phase equilibrium degassing; McAuliffe, 1971). Methane was measured on a Kristall-2000M gas chromatograph (Chromatec, Russia) equipped with a flame ionization detector. Sulfate and chloride were measured on a Staier ion chromatograph (Russia) after distillation and concentrating. Particulate organic carbon (POC) was determined as described previously (Vetrov et al., 2015). Sulfide was measured with $N, N$-dimethyl-p-phenylenediamine on an Ekspert-303 photometer (Russia). Three samples were used to obtain average values. Statistical processing of the results was carried out using MS Excel 2000.

For assessment of total microbial abundance $=$ total microbial number $(\mathrm{MA}=\mathrm{TMN})$ and microbial biomass, water samples in glass vials were fixed with glutaraldehyde at the final concentration of $2 \%$. Fixed samples $(5-10 \mathrm{~mL})$ were filtered through black polycarbonate $0.2-\mu \mathrm{m}$ filters (Millipore, United States). The filters were stained with acridine orange $(2 \mathrm{mg} / \mathrm{mL}$ ) (Hobbie et al., 1977) and examined under an Olympus BX 41 epifluorescence microscope equipped with an Image Scope Color $(\mathrm{M})$ visualization system. The cells were enumerated in 20 fields of view.

\section{Radiotracer Analysis}

The rates of microbial processes: light and dark $\mathrm{CO}_{2}$ assimilation (LCA and DCA), sulfate reduction (SR), methanogenesis (MG), and methane oxidation $(\mathrm{MO})$ were determined by radiotracer analysis using $\mathrm{NaH}^{14} \mathrm{CO}_{3},{ }^{14} \mathrm{CH}_{4}$, and $\mathrm{Na}_{2}{ }^{35} \mathrm{SO}_{4}$. LCA and DCA rates for each horizon were determined using one darkened vial and two transparent ones, to which $0.2 \mathrm{~mL}(20 \mu \mathrm{Ci})$ of a $\mathrm{NaH}^{14} \mathrm{CO}_{3}$ solution was added. DCMU [3-(3,4-dichlorophenyl)1,1-dimethylurea, $10^{-7} \mathrm{Mm}$ ] was used as a selective inhibitor of oxygenic photosynthesis (Legendre et al., 1983). The vials were attached to a nylon cord and suspended from an ice station in winter or from a buoy in summer. After incubation $(24 \mathrm{~h})$ the samples were fixed with $1 \mathrm{~mL}$ of diluted $\mathrm{HCl}$ and filtered through $0.2-\mu \mathrm{m}$ membranes. Production of oxygenic photosynthesis was calculated as the difference between the total and anoxygenic photosynthesis (the transparent vial with DCMU).

To determine the rates of other processes in the samples, incubation was also carried out in situ. After incubation, the samples were fixed with $1 \mathrm{~mL}$ of $0.1 \mathrm{M} \mathrm{KOH}$. The samples were then analyzed in the laboratory as was described previously (Savvichev et al., 2018). Radioactivity of the products of the studied microbial processes was measured using a TRI-Carb TR scintillation counter (Packard, United States). For determination of the LCA and DCA rates, ${ }^{14} \mathrm{C}-\mathrm{CO}_{2}$ both in bacterial cells and in the extracellular dissolved organic matter was accounted for. The confidence intervals for the LCA, DCA, MO, and SR values varied from 10 to $40 \%$.

\section{Carbon Isotope Analysis}

For determination of the carbon isotope composition of suspended organic matter $\left(\delta^{13} \mathrm{C}-\mathrm{C}_{\mathrm{org}}\right)$, water samples were filtered through calcined $47-\mathrm{mm}$ GF/F glass fiber filters. The filters were then dried at $60^{\circ} \mathrm{C}$. The filtrate was used to determine the carbon isotope composition of dissolved bicarbonate. Dried suspension on the GF/F filters was oxidized to $\mathrm{CO}_{2}$ by high-temperature incineration $\left(560^{\circ} \mathrm{C}\right)$ in the presence of copper oxide as a catalyst. Mineral carbon (dissolved inorganic carbon $=\mathrm{DIC}, \mathrm{HCO}_{3}{ }^{-}+\mathrm{CO}_{3}{ }^{2-}$ ) was converted to $\mathrm{BaCO}_{3}$, from which $\mathrm{CO}_{2}$ was produced by fusion of barium carbonate 


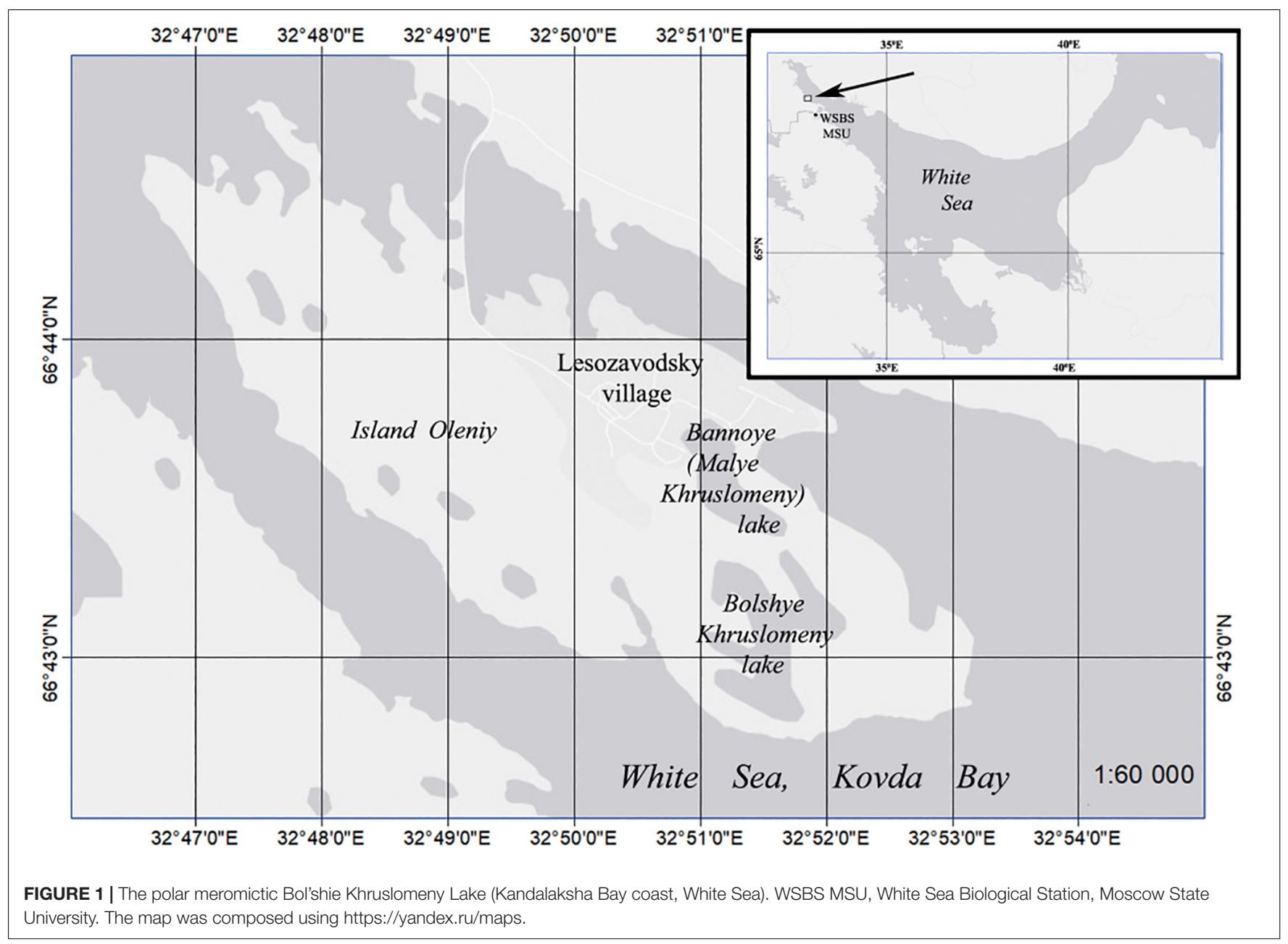

with tin salts at $560^{\circ} \mathrm{C}$. The value of $\delta^{13} \mathrm{C}$ characterizing the carbon isotope composition was determined on a Delta Plus mass spectrometer (Thermo Electron Corporation, Germany), using a PDB-calibrated standard, and calculated according to the known equation:

$$
\left.\delta^{13} C=\left[\left({ }^{13} C\right) /\left({ }^{12} C\right)\right]_{\text {sample }} /\left[\left({ }^{13} C\right) /\left({ }^{12} C\right)\right]_{\text {standard }}-1\right) \times 1000 \%
$$

where $\left[\left({ }^{13} \mathrm{C}\right) /\left({ }^{12} \mathrm{C}\right)\right]_{\text {sample }} /\left[\left({ }^{13} \mathrm{C}\right) /\left({ }^{12} \mathrm{C}\right)\right]_{\text {standard }}$ are the ratios of occurrence of ${ }^{12} \mathrm{C}$ and ${ }^{13} \mathrm{C}$ atoms in the sample and in the standard, respectively. The international PDB standard used has the isotope occurrence ration $\left({ }^{13} \mathrm{C}\right) /\left({ }^{12} \mathrm{C}\right)$ of 0.001172 (Craig, 1957). For methane, $\delta^{13} \mathrm{C}-\mathrm{CH}_{4}$ was measured on a TRACE GC gas chromatograph (Thermo Fisher Scientific, United States) coupled to a Delta Plus mass spectrometer. The error of the $\delta^{13} \mathrm{C}$ measurements did not exceed $\pm 0.1 \%$.

\section{DNA Extraction, Sequencing and Read-Centric Analysis}

Water samples from depths of 0.5, 1.5, 2.5, 3.25, 3.75, 4.25, 4.75, $5.25,10,15$, and 18 (March) and from 0.5, 2, 3, 3.25, 3.75, $4,4.25,4.5,4.75,5.25,7,10,15$, and $18 \mathrm{~m}$ (September) were collected by overflowing into 0.5 - L plastic bottles and sealed, avoiding gas bubbles. Microbial cells from a whole volume of each water sample $(0.5 \mathrm{~L})$ were concentrated on $0.2-\mu \mathrm{m}$ filters (CA membrane filter, Sartorius) on the day of sampling. The filters were homogenized by trituration with liquid nitrogen, and the preparation of metagenomic DNA was isolated by a method based on lysis of the cells followed by treatment with a detergent.

PCR amplification of the 16 S ribosomal RNA gene fragments containing the V3-V4 variable regions was carried out using the universal primers PRK341F (5' - CCTACGGGRBGCASCAG -3') and PRK806R (5' - GGACTACYVGGGTATCTAAT - 3') (Yu et al., 2005). PCR fragments were then sequenced on a GS FLX genome analyzer (Roche) according to the Titanium protocol using the GS FLX Titanium Sequencing Kit XL+. Creation of the library, its amplification, and sequencing were carried out according to the relevant Roche protocols.

Reads starting with the forward primer were selected and trimmed to the same length of $250 \mathrm{bp}$ using Mothur v.1.35.1 (Schloss et al., 2009). All the subsequent OTU analysis was done with Usearch v.11 (Edgar, 2010). Low-quality reads were filtered (fastq_maxee $=1.00$ ) and high-quality reads were clustered into OTUs at $97 \%$ identity level. At the clustering stage chimera and singleton sequences were removed by the Usearch algorithm. Then all reads, including low-quality ones and singletons, were 
mapped to OTU representative sequences at $97 \%$ global identity level to determine OTU size for each sample. OTU taxonomic identification was performed using the SINA online alignment and classification platform and the Silva v. 1.2.11 database with default parameters (Pruesse et al., 2012; Quast et al., 2013), and searching for close sequences in GenBank using the BLASTN protocol. When a sequence with more than 95\% similarity with the 16S rRNA gene of the described microorganism was detected, OTU was assigned to the corresponding genus. A total of 2177 OTU were classified, which included 196,564 sequences of $16 \mathrm{~S}$ rRNA genes.

\section{RESULTS}

\section{Hydrological Characterization of Lake B. Khruslomeny}

Sampling was carried out twice: from open water in September and from ice in March. The thermohaline structure of Lake B. Khruslomeny was rather stable, with seasonal changes occurring mostly in the upper layer with low salinity. In winter, water temperature immediately below the ice was positive, albeit low $\left(0.1-0.8^{\circ} \mathrm{C}\right)$, but at $2.0 \mathrm{~m}$ it already reached $2.3^{\circ} \mathrm{C}$, and then slightly increased with depth (Figure 2A). In September the temperature of the upper layer was $9.5^{\circ} \mathrm{C}$, with a wellpronounced warm layer (up to $13.5^{\circ} \mathrm{C}$ ) observed in the chemocline horizons. Below the chemocline the temperature decreased to $7^{\circ} \mathrm{C}$. In respect of salinity, three layers were revealed. The upper one (to 2-m depth), which was wind-mixed during the summer season, was desalinated (5-7\%). Salinity increased sharply in the intermediate layer $(2-4 \mathrm{~m})$. In the hypolimnion salinity was as high as $22-24 \%$.

The desalinated upper layer contained dissolved oxygen. In September this oxygen-saturated layer reached the depth of $2 \mathrm{~m}$, with oxygen concentration decreasing sharply in deeper layers; oxygen was detected by our instruments (with detection limit of $10 \mu \mathrm{mol} \mathrm{O} \mathrm{L}^{-1}$ ) as low as at $3.75 \mathrm{~m}$ (Figure 2B). In winter oxygen concentrations were lower, and it was not detected below $2.5 \mathrm{~m}$. The sulfide layer was located immediately below the oxic layer. Sulfide concentration in summer and in winter remained relatively stable. $\mathrm{HS}^{-}$concentration in the chemocline increased sharply with depth (to $0.5-4 \mathrm{mmol} \mathrm{L}^{-1}$ ) and reached $18 \mathrm{mmol}$ $\mathrm{L}^{-1}$ in the monimolimnion (Figure $2 \mathbf{B}$ ). The $\mathrm{pH}$ and Eh values in the oxic layer exhibited pronounced seasonal differences. In the upper layer, $\mathrm{pH}$ was 7.8-7.9 in September and 7.2 in March. In March, $\mathrm{pH}$ peaked in the 3.0-3.25-m layer. Below the chemocline, $\mathrm{pH}$ and Eh values in summer and winter remained almost the same ( $\mathrm{pH}=7.0-7.1$; Figure 3A).

The content of particulate organic carbon (POC) in September in the upper freshwater layer was $\sim 0.9-1.0 \mathrm{mg} \mathrm{C} \mathrm{L^{-1 }}$ (Figure 3B), which was more than five times higher than POC content in the White Sea water, but was common in freshwater reservoirs of the White Sea basin. POC content increased more than twofold in the intermediate saline layer. An extremely high POC level of $11.8 \mathrm{mg} \mathrm{C} \mathrm{L^{-1 }}$ was observed in September in the chemocline $(4.25 \mathrm{~m})$. This POC value was at least an order of magnitude higher than the concentrations observed in nonstratified basins. In the lower anoxic horizons below the 4.25-m layer, average POC levels were also more than twice higher than in the upper layers. In March, POC concentrations in all horizons were significantly lower than in September, reaching 0.075$0.14 \mathrm{mg} \mathrm{C} \mathrm{L}^{-1}$ in the oxic zone, up to $1.880 \mathrm{mg} \mathrm{C} \mathrm{L}^{-1}$ in the chemocline, and $0.780-1.570 \mathrm{mg} \mathrm{C} \mathrm{L}^{-1}$ in the near-bottom water.

\section{Microbial Processes in the Water Column Microbial Abundance and Biomass}

Microscopy of stained samples revealed heterogeneous distribution of microorganisms in the water column (Figure 4A). In both the summer and winter seasons, total microbial abundance (TMA) in the oxic layer was $0.2-0.8 \times 10^{6}$ cells

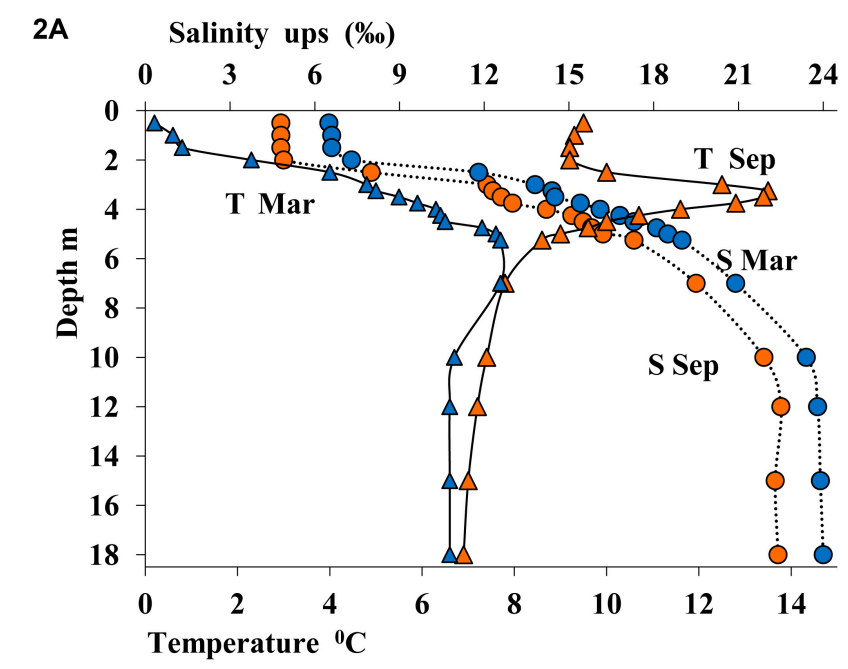

2B

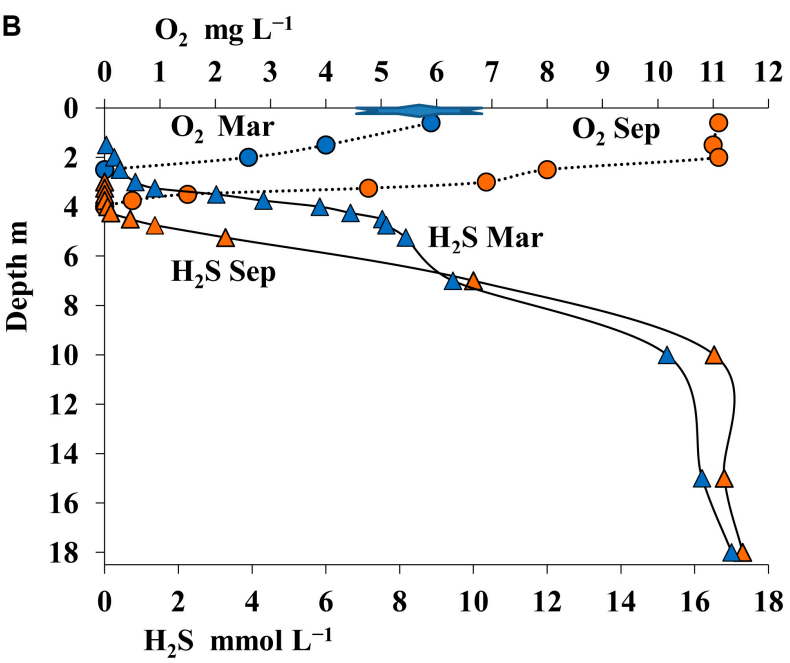

FIGURE 2 | Physicochemical conditions in the water column of Lake B. Khruslomeny in March (blue) and September 2017 (orange): temperature, ${ }^{\circ} \mathrm{C}$ and salinity, ups (A) and concentrations of sulfide, $\mathrm{mmol} \mathrm{L}^{-1}$ and oxygen, $\mathrm{mg} \mathrm{L}^{-1}$ (B). 

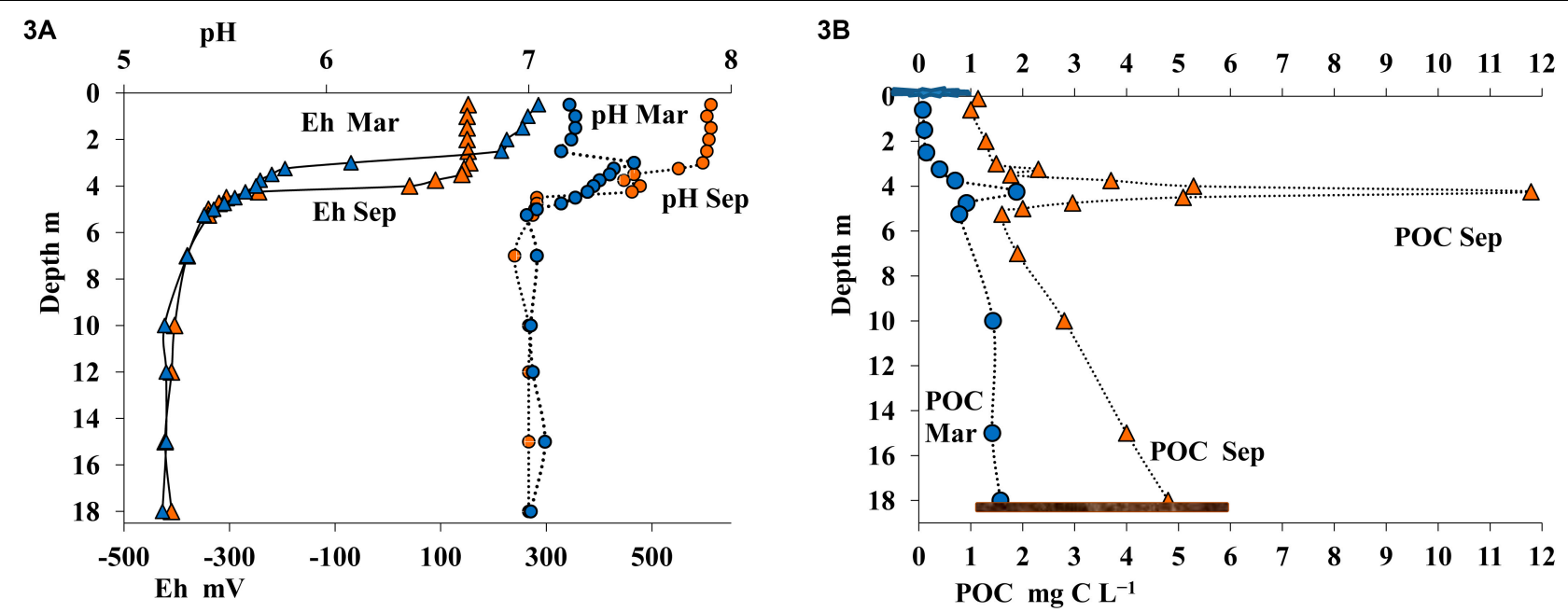

FIGURE 3 | Values of $\mathrm{pH}$ and Eh (A) and content of particulate organic carbon (POC, $\mathrm{mg} \mathrm{C} \mathrm{L}^{-1}$ ) (B) in the water column of Lake B. Khruslomeny in March (blue) and September (orange).

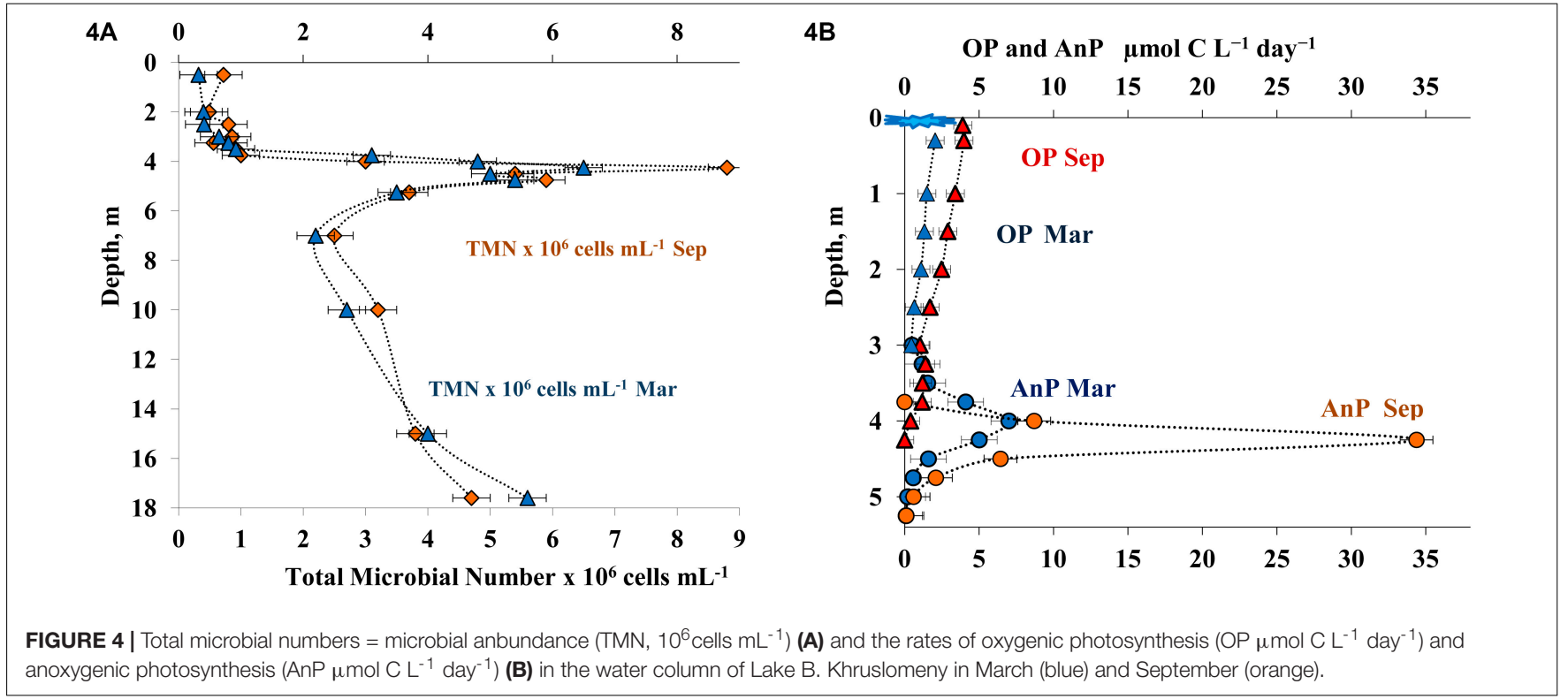

$\mathrm{mL}^{-1}$, which indicated the oligotrophic-mesotrophic state of the lake. At both seasons studied, TMA in the chemocline $(4.25 \mathrm{~m})$ was high, up to $8.8 \times 10^{6}$ cells $\mathrm{mL}^{-1}$ in September and up to $7.6 \times 10^{6}$ cells $\mathrm{mL}^{-1}$ in March. Below this peak, TMA decreased, but remained relatively high $\left(2.5-5.4 \times 10^{6}\right.$ cells $\left.\mathrm{mL}^{-1}\right)$. Bacterial cell volume in the water column varied from 0.3 to $0.6 \mu \mathrm{m}^{3}$, with $0.4-0.5 \mu \mathrm{m}^{3}$ in the chemocline and $0.3-0.4 \mu \mathrm{m}^{3}$ in the hypolimnion. The calculated microbial biomass was $40-80 \mu \mathrm{g} \mathrm{C}$ $\mathrm{L}^{-1}$ in the oxic layer, up to $880 \mu \mathrm{g} \mathrm{C} \mathrm{L}^{-1}$ in the chemocline layer, and $180-360 \mu \mathrm{g} \mathrm{C} \mathrm{L}^{-1}$ in the hypolimnion.

\section{Production of Oxygenic and Anoxygenic Photosynthesis, Dark $\mathrm{CO}_{2}$ Assimilation (DCA)}

Meromictic lakes, including Lake B. Khruslomeny, are characterized by two types of photosynthesis: oxygenic photosynthesis (OP), carried out in the upper water layer by cyanobacteria and eukaryotic algae, and anoxygenic photosynthesis (AnP), carried out in the anoxic zone by anoxygenic phototrophic bacteria (APB). In September, relatively low OP rates of $1.0-3.8 \mu \mathrm{mol} \mathrm{C} \mathrm{L}^{-1}$ day $^{-1}$ were observed in the oxic layer $(0-3.75 \mathrm{~m})$ (Figure 4B). The rate of oxygenic photosynthesis decreased significantly at the lower border of the oxic layer. At the same time, a pronounced AnP

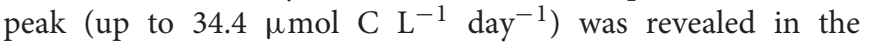
upper part of the sulfide-containing layer, at the horizons of 4.25 and $4.5 \mathrm{~m}$. The rate of photosynthesis decreased rapidly with depth, reaching almost zero at $5.25 \mathrm{~m}$. During the spring sampling (ice-covered period), OP rate was somewhat lower than in autumn (up to $2 \mu \mathrm{mol} \mathrm{C} \mathrm{L}{ }^{-1}$ day $^{-1}$, Figure 4B) and was restricted to a narrow horizon below the ice. Significant 
rates of photosynthesis in winter indicated the possibility of light-induced methane oxidation. The relevant experiments were carried out in September (see below). The peak of anoxygenic photosynthesis occurred at this period in the 3.75-4.0 m horizon and was more shallow than in autumn. The highest AnP rate in March was $7.0 \mu \mathrm{mol} \mathrm{C} \mathrm{L}{ }^{-1}$ day $^{-1}$.

Dark $\mathrm{CO}_{2}$ assimilation (DCA) is a summarized parameter including both the rate of heterotrophic carboxylation and autotrophic chemosynthetic $\mathrm{CO}_{2}$ assimilation (Alonso-Saez et al., 2010). In September (Figure 5A), DCA was low in the

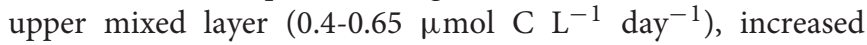
sharply in the chemocline, reaching the maximum at $4.25 \mathrm{~m}$

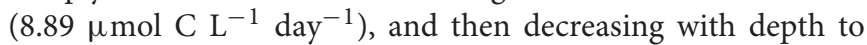
2.9-4.5 $\mu \mathrm{mol} \mathrm{C} \mathrm{L}{ }^{-1} \mathrm{day}^{-1}$ (Figure 5A). In March, high DCA was detected in the layer immediately below the ice $(2.83 \mu \mathrm{mol}$ $\mathrm{C} \mathrm{L}^{-1}$ day $^{-1}$ ), with the DCA peak of $8.0 \mu \mathrm{mol} \mathrm{C} \mathrm{L}{ }^{-1}$ day $^{-1}$ occurring at $4.25 \mathrm{~m}$, similar to the summer season; however, unlike summer, DCA remained high at $4.75 \mathrm{~m}(7.7 \mu \mathrm{mol}$ $\mathrm{C} \mathrm{L}^{-1}$ day $^{-1}$ ).

\section{Bacterial Sulfate Reduction}

Radiotracer analysis showed first indications of sulfate reduction in March and September at the depths of 3.25 and $3.75 \mathrm{~m}$, respectively, which corresponded to the upper horizon of the chemocline zone (Figure 5B). Both in summer and in winter sulfate reduction rates increased with depth and peaked (up to 0.6-1.1 $\mu \mathrm{mol} \mathrm{S} \mathrm{L}{ }^{-1} \mathrm{day}^{-1}$ ) in the lower chemocline $(4.75 \mathrm{~m})$. Below $5.25 \mathrm{~m}$, sulfate reduction rates decreased to $0.25 \mu \mathrm{mol} \mathrm{S} \mathrm{L}{ }^{-1} \mathrm{day}^{-1}$ at $7.0 \mathrm{~m}$ and $0.02-0.05 \mu \mathrm{mol} \mathrm{S} \mathrm{L} \mathrm{L}^{-1}$ $\mathrm{day}^{-1}$ in the near-bottom water layer. Sulfate concentrations are an indirect indicator of the rates of microbial processes of the sulfur cycle (both oxidative and reductive). In marine basins with a constant ratio of the major salts, absolute sulfate concentrations may be used for the purpose. In stratified basins with salinity gradients in the water column, using sulfate share, expressed as a sulfate-chloride coefficient $\left(\mathrm{SO}_{4}{ }^{2-} / \mathrm{Cl}^{-} \times 1000\right)$, is recommended. This coefficient is almost constant in ocean water (139.6) (Lyman and Fleming, 1940). The data shown on Figure 5B demonstrate variation of this coefficient from 132 to 138 in the oxic zone of Lake B. Khruslomeny (to the depth of $2.50 \mathrm{~m}$ ); these values were close to those of seawater diluted by runoff from the surface. At the depths of 3.25$4.5 \mathrm{~m}$, the share of sulfate was higher than in the surface layer (144-156). This was an indication that production of additional sulfate due to light-dependent sulfide oxidation by anoxygenic phototrophic bacteria was probably more intense than sulfate consumption by sulfate reducers. The sulfatechloride coefficient decreased to 127 at $7.0 \mathrm{~m}$. Thus, the equilibrium of the sulfur balance was shifted to reductive processes, resulting in sulfate consumption and release of reduced sulfur compounds. At the lower horizons, sulfate ratio to chloride dropped sharply (to 2-5 in the near-bottom layers, which corresponded to $0.09-0.30 \mathrm{mmol} \mathrm{SO}_{4}{ }^{2-} \mathrm{L}^{-1}$ ), which was an important biogeochemical result of active microbial sulfate reduction.

\section{Dissolved Methane in Lake B. Khruslomeny}

The results of the measurements of methane distribution it the water column of Lake B. Khruslomeny in different seasons are presented on Figures 6A,B. Methane was detected throughout the water column. In September, its concentration in the upper layer (above the chemocline) was $0.2-0.6 \mu \mathrm{mol} \mathrm{L}^{-1}$, increased to $14-30 \mu \mathrm{mol} \mathrm{L}-1$ in the chemocline, and then increased still further with depth, reaching a very high value of $1820 \mu \mathrm{mol} \mathrm{CH}_{4}$ $\mathrm{L}^{-1}$ in the near-bottom horizon. In winter methane was found immediately below the ice $\left(3.2 \mu \mathrm{mol} \mathrm{L}^{-1}\right)$, its concentration increased in the lower chemocline and, similar to the autumn season, was very high in the near-bottom horizon $(1680 \mu \mathrm{mol}$ $\left.\mathrm{L}^{-1}\right)$. The most abrupt change in methane concentration occurred in the horizons at 3.75-5.5 $\mathrm{m}$.
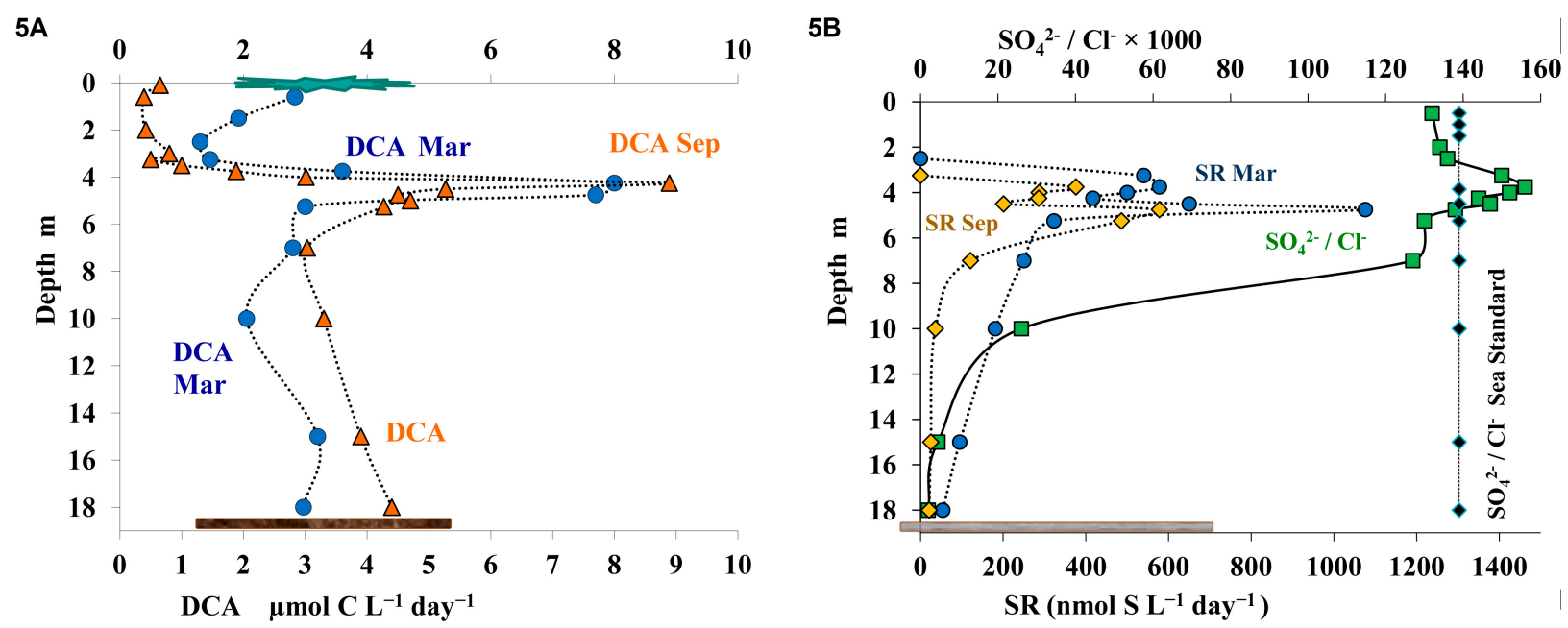

FIGURE 5 | Rates of dark carbon assimilation (DCA, $\mu \mathrm{mol} \mathrm{C} \mathrm{L^{-1 }}$ day ${ }^{-1}$ ) (A) and of sulfate reduction (SR) in March (blue) and September (orange), and the ratio of sulfate and chloride ions $\left(\mathrm{SO}_{4}{ }^{2-} / \mathrm{Cl}^{-} \times 1000\right)(\mathbf{B})$ in the water column of Lake B. Khruslomeny (green). Seawater standard (black) corresponds to SO ${ }_{4}^{2-}=2.649$; $\mathrm{Cl}^{-}=18.980 \mathrm{~g} / \mathrm{kg} ; \mathrm{SO}_{4}{ }^{2-} / \mathrm{Cl}^{-} \times 1000=139.6$ 

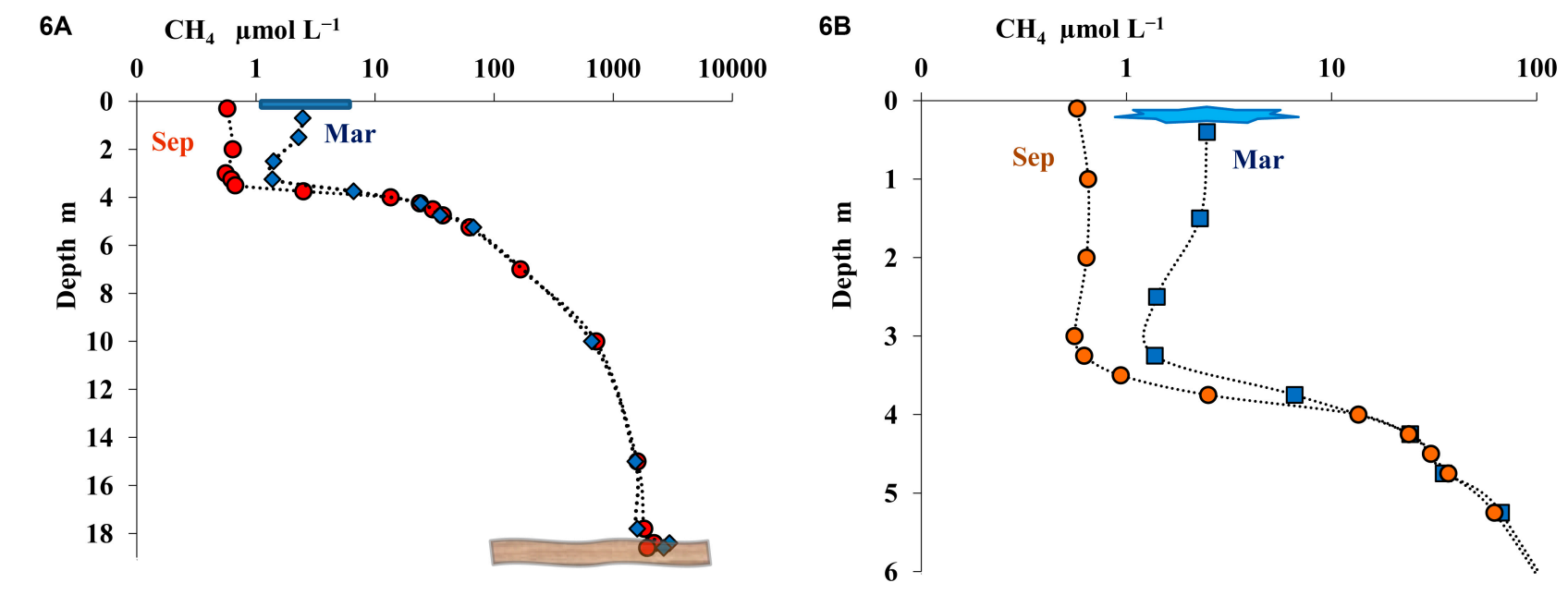

FIGURE 6 | Concentration of methane $\left(\mathrm{CH}_{4}, \mu \mathrm{mol} \mathrm{L}-1\right)$ in the water column of Lake B. Khruslomeny in March (blue) and September (orange) in the water column (A) and in the mixolimnion and chemocline layers (B).

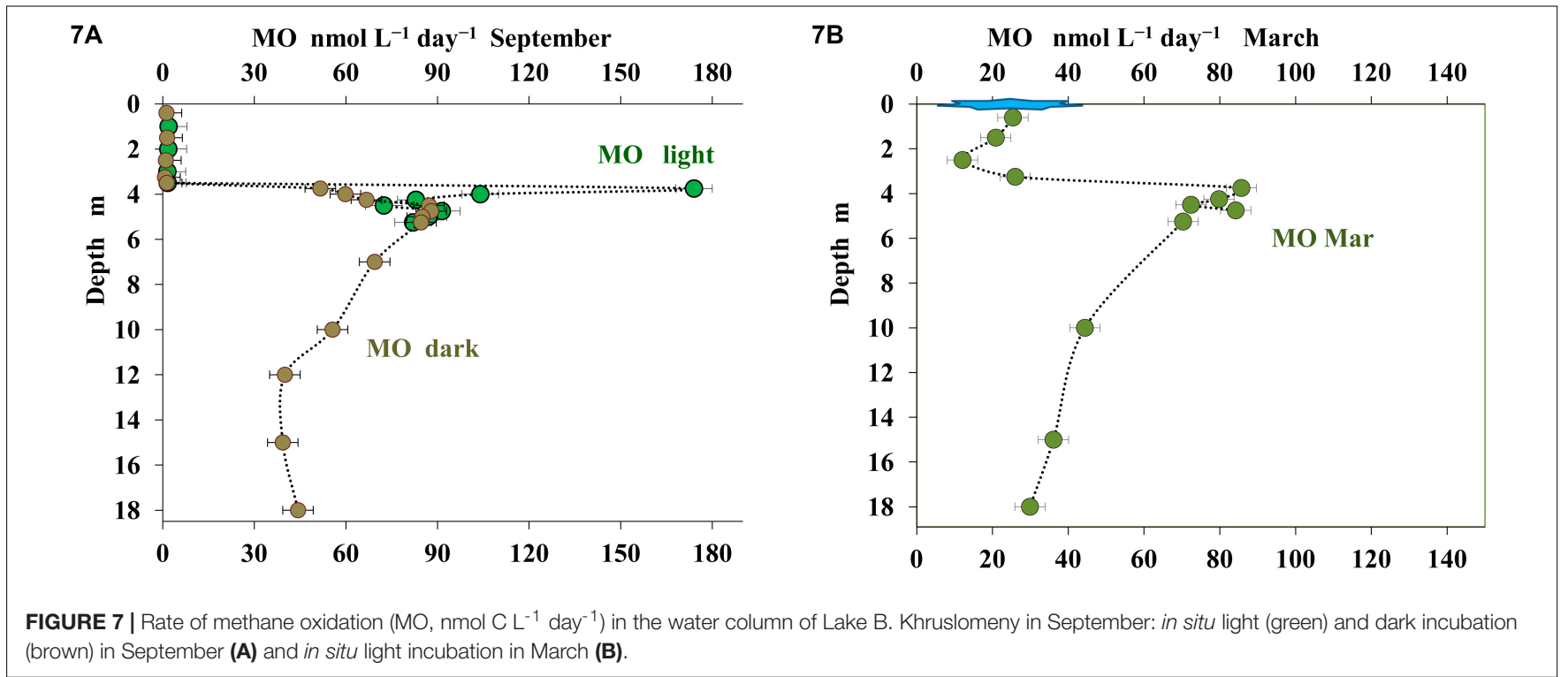

\section{Rates of Methane Oxidation}

Both in March and in September MO was shown to occur throughout the water column, from the surface to the near-bottom zone (Figures 7A,B). MO rate in the upper layer (to the depth of $3.5 \mathrm{~m}$ ) was very low, at the limit of the sensitivity of the method (up to $1 \mathrm{nmol} \mathrm{CH}_{4} \mathrm{~L}^{-1} \mathrm{day}^{-1}$ ). A rapid increase in MO rate with a peak of $100-170 \mathrm{nmol} \mathrm{CH}_{4} \mathrm{~L}^{-1}$ day $^{-1}$ occurred at the depths from 3.75 to $4.0 \mathrm{~m}$. In situ incubation at the depths of 3.75 and $4.0 \mathrm{~m}$ revealed pronounced differences in $\mathrm{MO}$ rates between the samples in transparent and darkened vials. Light-induced MO activation was less pronounced in the $4.25 \mathrm{~m}$ horizon, while no stimulation by light was observed for the samples from deeper horizons (Savvichev et al., 2019).

In March, methane oxidation was detected in all horizons, up to and including the under-ice layer. The rate of this process at depths less than $3.25 \mathrm{~m}$ did not exceed $26 \mathrm{nmol} \mathrm{CH}_{4} \mathrm{~L}^{-1}$ day $^{-1}$.
At depth of 3.75-5.25 m, MO rates were higher $\left(70-85 \mathrm{nmol} \mathrm{CH}_{4}\right.$ $\left.\mathrm{L}^{-1} \mathrm{day}^{-1}\right)$. No experiments on MO stimulation by light were carried out in March.

\section{Isotope Composition of Particulate Organic Carbon, Dissolved Mineral Carbon, and Methane Carbon}

The data on isotope composition of particulate organic carbon (POC) $\left(\delta^{13} \mathrm{C}_{\mathrm{Corg}}\right)$ and dissolved mineral carbon $\left(\delta^{13} \mathrm{C}-\mathrm{HCO}_{3}{ }^{-}\right)$ are presented on Figure 8.

Carbon isotope composition of POM in the uppermost $1 \mathrm{~m}$ of the lake ( $\delta^{13} C_{\text {Corg }}$ from -21.8 to $-20.4 \%$ in March and from -23.0 to $-22.2 \%$ in September) was similar to the values for marine phytoplankton. Higher content of the light carbon isotope in September indicated the effect of freshwater inflow from 

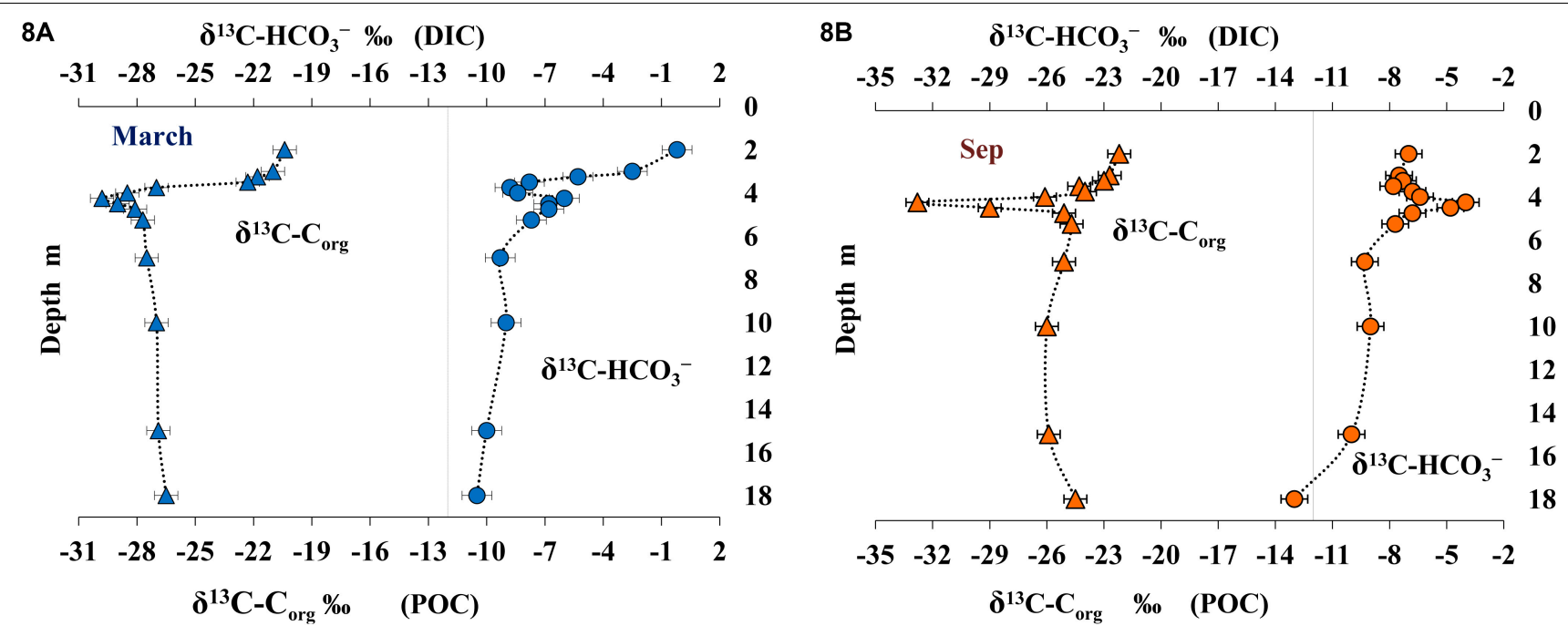

FIGURE 8 | Isotope composition of particulate organic carbon (POC) $\left(\delta^{13} \mathrm{C}_{\text {org }} \%\right)$ and dissolved inorganic carbon (DIC) $\left(\delta^{13} \mathrm{C}-\mathrm{HCO}_{3},-{ }^{\circ}\right)$ in $\mathrm{March}(\mathbf{A})$ and September (B).

surrounding swamped areas. The under-ice layer with a local maximum of oxygenic photosynthesis (Figure 4B) was enriched with the heavier carbon isotope $\left(\delta^{13} \mathrm{C}_{\mathrm{Corg}}=-20.4 \%\right)$ from POC of newly developed autochthonous phytoplankton. Mineral carbon of the under-ice layer was enriched with the heavy isotope $\left(\delta^{13} \mathrm{C}_{-} \mathrm{HCO}_{3}{ }^{-}\right.$from -2.5 to $\left.-0.2 \%\right)$. Increased share of the heavy carbon isotope resulted from its fractionation by oxygenic phototrophs, which preferentially consume the light isotope of mineral carbon. This effect was less pronounced in September $\left(\delta^{13} \mathrm{C}-\mathrm{HCO}_{3}{ }^{-}\right.$from -7.5 to $\left.-7.0 \%\right)$. In the upper water layer, the hugest efficiency of carbon isotope fractionation $\left[\Delta=\left(\delta^{13} \mathrm{C}_{\mathrm{Corg}}\right.\right.$ $\left.-\delta^{13} \mathrm{C}_{-} \mathrm{HCO}_{3}{ }^{-}\right)=20.2 \%$ ] was revealed in the under-ice water horizon. POM carbon isotope composition became significantly lighter in the upper part of the chemocline $\left(\delta^{13} \mathrm{C}_{\mathrm{Corg}}\right.$ from -29.8 to $-27.0 \%$ in March and from -32.8 to $-26.1 \%$ in September; Figures $8 \mathrm{~A}, \mathbf{B})$. The carbon isotope composition of carbonate and $\mathrm{CO}_{2}$ also changed within this horizon $\left(\delta^{13} \mathrm{C}-\mathrm{HCO}_{3}{ }^{-}=-6.0 \%\right.$ in March and $-4.0 \%$ in September; Figures 8A,B). Changes in the composition of mineral carbon resulted from two processes: $\mathrm{CO}_{2}$ release due to oxidation of methane arriving from deeper layers and $\mathrm{CO}_{2}$ consumption by anoxygenic photosynthesis. As a product of methanotrophic activity, the carbon of carbonates and $\mathrm{CO}_{2}$ inherits the lighter isotopic composition of methane. The newly produced light mineral carbon is in turn consumed by the anoxygenic phototrophic bacterial community and incorporates into organic matter produced in this layer with high microbial activity. The ${ }^{13} \mathrm{C}_{\mathrm{Corg}}$ in the deeper anoxic layer varied from -27.5 to $-26.5 \%$ in March and from -26.0 to $-24.5 \%$ in September. The mineral carbon was enriched with the light isotope $\left(\delta^{13} \mathrm{C}-\mathrm{HCO}_{3}{ }^{-}\right.$varied from -13.0 to $\left.-9.0 \%\right)$. Lighter isotope composition of mineral carbon in the nearbottom horizons resulted from intense processes of anaerobic degradation of OM produced by the community of anoxygenic phototrophs, chemotrophs, and methanotrophs and arriving from higher water layers. The efficiency of carbon isotope fractionation in the near-bottom anoxic layer was lower than in the chemocline and the subsurface horizons $(\Delta=16-18 \%$ in March and $12-17 \%$ in September).

Dissolved methane from the near-bottom water, where its concentration was very high both in March and September, was isotopically light $\left(\delta^{13} \mathrm{C}_{\mathrm{CH} 4}\right.$ from -78.0 to $-80.4 \%$, Figures 9A,B). The content of isotopically light methane carbon decreased in higher horizons, including the chemocline $\left(\delta^{13} \mathrm{C}_{\mathrm{CH} 4}\right.$ from -64.0 to $-60.0 \%$; Figure 9) due to its microbial consumption (oxidation). In September, carbon isotope composition of dissolved methane was determined for the layers from the bottom to $3.75 \mathrm{~m}\left(\Delta^{13} \mathrm{C}_{\mathrm{CH} 4}=-60.0 \%\right)$. The concentration of dissolved methane in the upper layers was insufficient for analysis during this season. The data on methane carbon isotope composition in the three horizons above the chemocline $\left({ }^{13} \mathrm{C}_{\mathrm{CH}} 4\right.$ from -65.0 to $\left.-63.5 \%\right)$ were obtained in March (Figure 9B). A significant increase in the content of the heavier carbon isotope indicated fractionation resulting in the course of microbial (aerobic) methane oxidation.

\section{Microbial Community of the Water Column of Lake B. Khruslomeny}

Microbial communities of the water column of the lake in March and September 2017 (11 horizons in March and 15 in September) were characterized by analyzing their 16S rRNA gene sequences (Figure 10).

\section{Oxic Zone}

Pro- and eukaryotic microorganisms carrying out oxygenic photosynthesis were the primary producers in the oxic upper layer of the lake. The composition of the phototrophic community in September and March was found to differ significantly. Cyanobacteria predominated (7 to $12 \%$ of the community) in the upper horizon (0-3.35 m) in September. Almost all of them belonged to the genus Cyanobium of the 

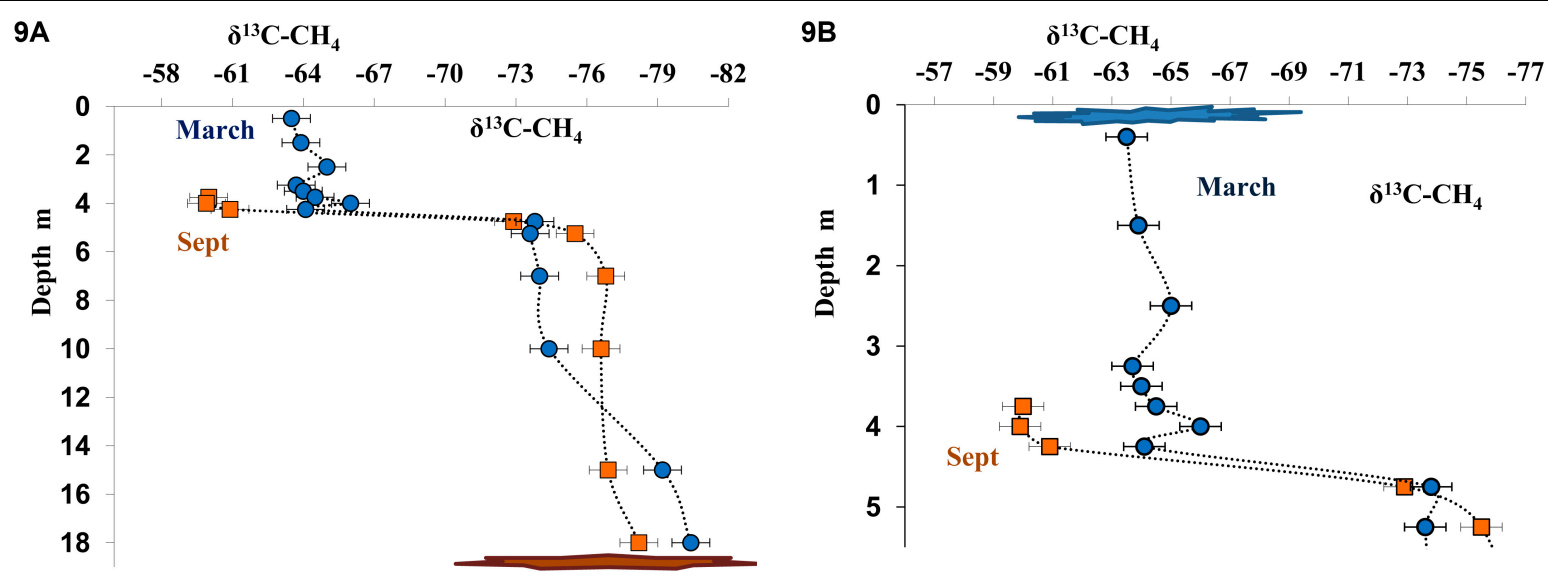

FIGURE 9 | Isotope composition of methane carbon $\left(\delta^{13} \mathrm{C}-\mathrm{CH}_{4}, \%\right)$ in the water column of Lake B. Khruslomeny in March (blue) and September 2017 (orange) in the water column (A) and in the chemocline and mixolimnion layers (B).

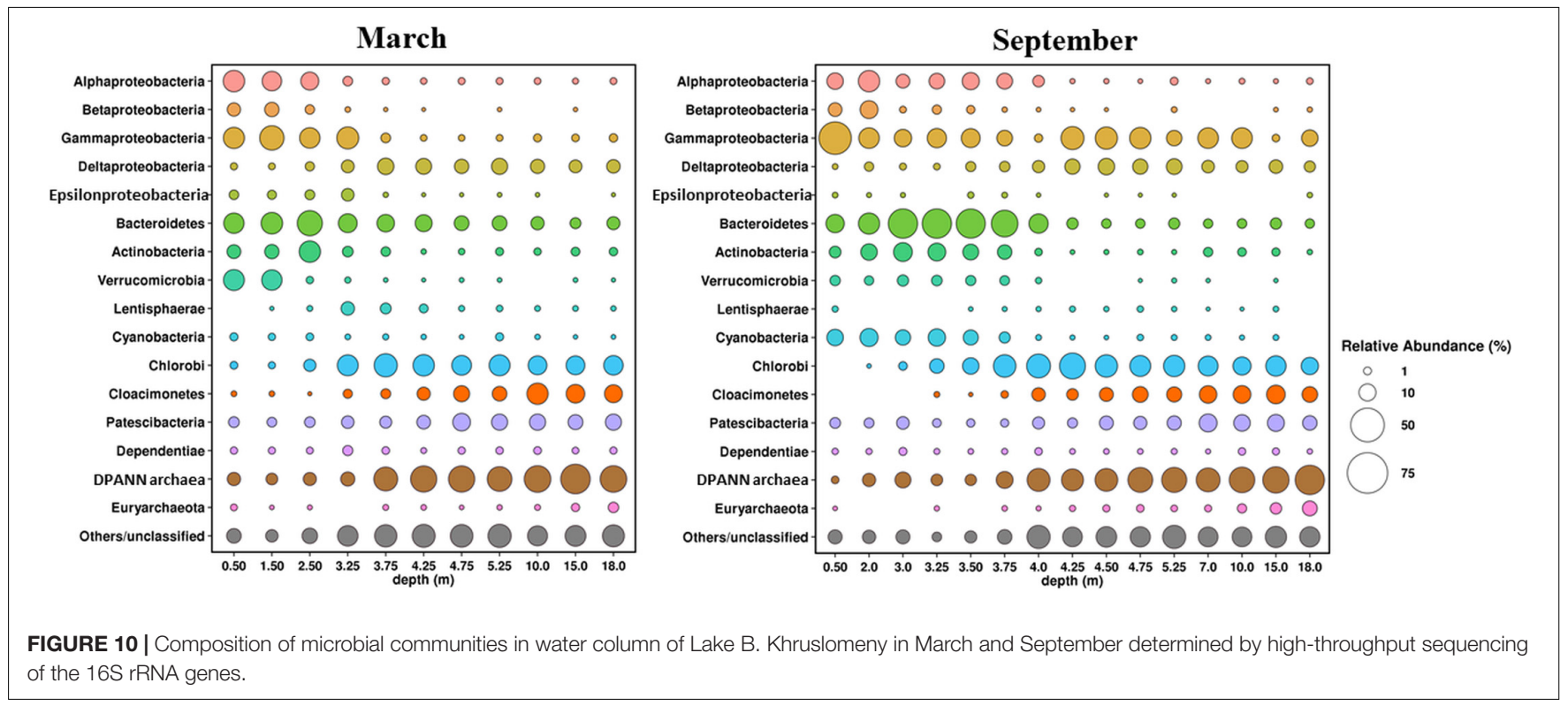

order Synechococcales, which is common in Arctic basins (Van Hove et al., 2008). During the ice-covered season the share of cyanobacteria in the uppermost water horizon was $\sim 1 \%$, probably due to decreased illumination. The most numerous bacterial groups in the upper layer were Alphaproteobacteria (6-18\%), Gammaproteobacteria (11-46\%), Bacteroidetes (12-36\%), Actinobacteria (4-13\%), and Verrucomicrobia (2$3 \%)$. Cultured members of most of these groups are aerobic heterotrophs. Thus, predominant Alphaproteobacteria belonged to Rhodobacteraceae and Hyphomonadaceae, including members of the genus Hyphomonas, common in marine environments, including the Arctic seas (Li et al., 2014), as well as to the uncultured clade SAR11, one of the most abundant cosmopolitan lineages of marine plankton (Giovannoni, 2017). Predominant members of the Gammaproteobacteria belonged to the genera Aeromonas, Shewanella, and Psychrobacter, while in the uppermost $0.5-\mathrm{m}$ layer, the genus Pseudomonas prevailed, constituting $\sim 20 \%$ of the community. The Bacteroidetes was one of the most diverse microbial groups containing 183 OTUs, mainly belonging to the orders Chitinophagales, Sphingobacteriales, and Flavobacteriales, as well as to the uncultured lineage VC2.1 Bac22. All these groups comprise typical aquatic heterotrophs. Predominant actinobacteria were Candidatus Aquiluna (family Microbacteriaceae), actinorhodopsin-carrying photoheterotrophs isolated from marine and freshwater environments (Kang et al., 2012). Betaproteobacteria were numerous $(6-11 \%)$ only in the desalinated upper layer at the depths not exceeding $2 \mathrm{~m}$, while deeper their share was only 1-2\%. Most of the Betaproteobacteria belonged to two groups of the family Burkholderiaceae, the genus Limnohabitans, comprising freshwater aerobic anoxygenic phototrophic bacteria, which were found in pelagic zones of various freshwater habitats (Kasalický et al., 2018), and an uncultured MWH-UniP1 aquatic group. The same bacterial 
phyla, except for Cyanobacteria, were predominant in the oxic upper zone during winter. The share of Verrucomicrobia in the desalinated upper layer at $0.5-1.5 \mathrm{~m}$ was significantly higher (16$17 \%$ ) due to abundance of three OTUs, two of which belonged to the genus Luteolibacter (family Rubritaleaceae), while the third belonged to the genus Prosthecobacter. Members of these genera have been isolated from diverse aquatic ecosystems, including Arctic soils and lakes (Jiang et al., 2012). Some strains were shown to degrade the components of algal cells (Ohshiro et al., 2012; Lee et al., 2014). Active algal growth in the under-ice layer probably favored development of these verrucomicrobia.

\section{Chemocline}

Green sulfur bacteria of the phylum Chlorobi capable of anoxygenic photosynthesis constituted $\sim 20 \%$ of the bacterial community both in September and in March. They were almost exclusively represented by a single OTU, which was identified as Chlorobium phaeovibrioides. Members of this species can form very dense colored layers in the water, acting as bacterial filters preventing sulfide release from the monimolimnion to the epilimnion (Savvichev et al., 2018). C. phaeovibrioides has been found in the chemocline and hypolimnion of meromictic basins at the Kandalaksha coast, White Sea. Metagenomic analysis of the water sample from the chemocline of Lake B. Khruslomeny collected in March 2017 revealed the same species, which was responsible for $\sim 25 \%$ of the metagenome (Kadnikov et al., 2019a). In September, the dominant groups in the chemocline zone $(3.5-3.75 \mathrm{~m})$ included Bacteroidetes (30-36\%), Alphaproteobacteria (8-10\%), Gammaproteobacteria (8-13\%), Actinobacteria (7-8\%), Cyanobacteria (3-7\%), Deltaproteobacteria (2-3\%), Verrucomicrobia ( 2\%), and archaea of the candidate phylum Woesearchaeia (5-14\%). The lineages found among the Bacteroidetes, Gammaproteobacteria, Cyanobacteria, Actinobacteria, and Verrucomicrobia were mainly the same which were detected in the upper layer. Among the Alphaproteobacteria, the main components of the community were Rhodobacteraceae and Magnetospiraceae, while Hyphomonadaceae and SAR11, which were present in the upper oxic zone, were not found. In the upper part of the chemocline $(3.5-3.75 \mathrm{~m})$, where methane oxidation was active (Figure 7A), members of the genus Methyloprofundus (Methylomonaceae, Gammaproteobacteria) were revealed; these organisms have been isolated from marine sediments and water column (Tavormina et al., 2015). Their share at $3.75 \mathrm{~m}$ was as high as $2.4 \%$. These bacteria were nearly absent in September samples from the upper oxic zone.

In winter the chemocline was closer to the surface, at the depths of 2.5-3.25 m. While the composition of the chemocline microbial community in March was mostly similar to that observed in September, some significant differences were found. First, the share of cyanobacteria in the chemocline zone was lower, not exceeding 1\%. Second, in winter methanotrophs occupied higher horizons, including the under-ice layer (0.5$3.25 \mathrm{~m}$ ), and their share in the community at $1.5 \mathrm{~m}$ was as high as $14 \%$. Apart from Methyloprofundus, Methylobacter was also present in the methanotrophic community. Members of this genus have been isolated from Arctic swamp soils, Svalbard (Wartiainen et al., 2006; Kallistova et al., 2014). Third, members of the genus Thiomicrorhabdus, chemolithotrophic gammaproteobacteria oxidizing reduced sulfur compounds at low levels of oxygen (Boden et al., 2017), were found in the chemocline. At the depths of 2.5 and $3.32 \mathrm{~m}$ the shares of Thiomicrorhabdus were 7 and 18\%, respectively. These organisms were not revealed in September samples, and in March their share in other horizons did not exceed $1.5 \%$. Another group of chemolithoautotrophic sulfur-oxidizing bacteria, members of the genus Sulfurimonas (Epsilonproteobacteria), was also revealed in the chemocline and above. Their share was 1.7 to $4.5 \%$ at the depths of $0.5-3.25 \mathrm{~m}$ and less than $0.2 \%$ at greater depths; in September, they occurred in minor amounts $(0.5 \%)$ only in the chemocline $(3.25 \mathrm{~m})$. The winter samples also contained high numbers of bacteria of the phylum Lentisphaerae in the lower chemocline zone (3.25 and $3.75 \mathrm{~m})$.

\section{Anoxic Zone}

The hypoliminion microbial communities (samples collected from the depths exceeding $4.25 \mathrm{~m}$ in September and $3.75 \mathrm{~m}$ in March) differed in composition from those of the upper oxic zone and the chemocline, while the differences between the March and September samples were, barring some exceptions, less pronounced. The five groups most numerous in September were Chlorobi (10-27\%), Gammaproteobacteria (1-21\%), Cloacimonetes (4-13\%), Deltaproteobacteria (3-9\%), and Patescibacteria $(2-11 \%)$. The shares of other bacterial phyla did not exceed $1 \%$. Over $90 \%$ of the sequences of the most numerous phylum, Chlorobi, belonged to a single species Chlorobium phaeovibrioides.

The phylum Candidatus Cloacimonetes (previously known as candidate division WWE1) was originally observed in anaerobic digesters (Solli et al., 2014). Analysis of the genomes of these microorganisms revealed their ability to utilize proteinaceous substrates (Pelletier et al., 2008), cellulose (Limam et al., 2014), and propionate (Nobu et al., 2015), as well as to form syntrophic associations with other microorganisms (Dyksma and Gallert, 2019). Cloacimonetes were revealed in various anaerobic ecosystems, including the Black Sea sulfide zone, where they were found to be responsible for degradation of dissolved organic matter (Suominen et al., 2019). The highest share of Cloacimonetes (8-13\%) occurred at the depths below $7 \mathrm{~m}$. The closest relatives have been found in the sediments of meromictic lakes and in Pacific hydrothermal vents.

Most of the Deltaproteobacteria belonged to Desulfarculaceae and Desulfobacteraceae; cultured members of these families are sulfate reducers. The most numerous OTU was assigned to the genus Desulfatiglans. Characterized Desulfatiglans isolates are dissimilatory sulfate reducers capable of degrading aromatic compounds (Suzuki et al., 2014), while Desulfatiglansrelated microorganisms found in marine sediments could be metabolically more diverse: apart from sulfate reduction, some of them exhibited the genetic potential for growth by acetogenesis, fermentation, and reductive dehalogenation (Jochum et al., 2018). Members of the family Syntrophaceae were also found 
at the depths below $7 \mathrm{~m}$. Cultured members of this family are syntrophs degrading short-chain fatty and aromatic acids to produce acetate, formate, and hydrogen in co-cultures with hydrogen-consuming methanogens or sulfate reducers (Elshahed and McInerney, 2001; McInerney et al., 2007).

Gammaproteobacteria constituted 8 to $21 \%$ of the microbial community in all samples below the chemocline, except for $15 \mathrm{~m}$ where their share was only $0.92 \%$. A single OTU assigned to the genus Pseudoalteromonas, which was numerous in the chemocline zone as well, was responsible for this heterogeneity. Pseudoalteromonas species are a group of mostly aerobic marine bacteria frequently found in various environments, including cold habitats and deep-sea sediments (Parrilli et al., 2019). In the samples collected from the depths of $0.5,2,3,4$, and $15 \mathrm{~m}$ in September, as well as in all March samples, the share of this OTU did not exceed $1 \%$. Since Pseudoalteromonas species are generally found in association with marine eukaryotes (Holmström and Kjelleberg, 1999), detected Pseudoalteromonas were probably also associated with macroscopic objects accidentally collected with the samples.

Members of the superphylum Patescibacteria, also known as the candidate phyla radiation (CPR), a large monophyletic group in the tree of life, which lacks cultivated representatives, constituted a significant part of the hypolimnion microbial community (2 to 12\%). Members of the Patescibacteria group have been found in geothermal pools, marine and freshwater sediments, soil, and other mostly anoxic organicrich environments. Genomics studies of Patescibacteria revealed that they have small genomes ( $\sim 1 \mathrm{Mbp}$ or less) with limited capacities for fermentative metabolism, and lacked amino acid, nucleotide, and lipid biosynthetic pathways, which suggests the lifestyle of a scavenger or symbiot/parasit (Brown et al., 2015; Castelle et al., 2018).

Both in March and September archaea constituted from one-third to a half of all detected microorganisms in the hypolimnion samples. The putative methanogens constituted a small part of the archaeal community and occurred mostly in the samples of near-bottom water (depths of 15 and $18 \mathrm{~m}$ ), where their shares among all $16 \mathrm{~S}$ rRNA gene sequences were 0.9 and $2 \%$ in March and 3 and $6 \%$ in September, respectively. The total share of methanogenic archaea in other samples did not exceed $0.5 \%$. Most methanogens belonged to hydrogenotrophic archaea of the order Methanomicrobiales; aceticlastic methanogens of the family Methanosaetaceae (mostly the genus Methanosaeta) and methylotrophic methanogens of the family Methermicoccaceae were also revealed. Notably, we found no $16 \mathrm{~S}$ rRNA gene sequences related to known anaerobic methane oxidizers (ANME-1, 2, and 3).

Members of the DPANN superphylum, mainly Woesearchaeota, were the predominant archaeal group responsible for up to $50 \%$ of all $16 \mathrm{~S}$ rRNA gene sequences. Members of the DPANN superphylum (Rinke et al., 2013) are widespread in various aquatic ecosystems, including boreal and subarctic lakes (Restrepo-Ortiz and Casamayor, 2013; OrtizAlvarez and Casamayor, 2016; Carnevali et al., 2018; Kadnikov et al., 2019b; Kallistova et al., 2019).

\section{DISCUSSION}

Since microbial communities developing in the chemocline of meromictic lakes carry out geochemically important redox processes, such basins are of interest to microbiologists. As a rule, two layers of photosynthetic activity are present in meromictic lakes: the layer of oxygenic photosynthesis in the surface or subsurface horizon (meters to several tens of meters thick) and the layer of anoxygenic photosynthesis, which usually coincides with the chemocline (oxycline) and is one to several meters thick. As a rule, oxygenic photosynthetic production in meromictic lakes exceeds the anoxygenic one, since the community of anoxygenic phototrophic bacteria relies on residual sunlight penetrating the upper water layers inhabited by cyanobacteria and algae. If the chemocline horizon is located in the photic zone, anoxygenic phototrophic bacteria in high or very high numbers constitute the basis of the chemocline microbial community. Dense microbial layers, easily discernible due to their green or red pigmentation, are sometimes termed bacterial plates (Vila et al., 1998; Garcia-Gil et al., 1999; Camacho et al., 2001).

Meromictic basins (lakes, ponds, bays, and fjords) are known on all continents and many islands (Zadereev et al., 2017). They vary widely in size, from 1 acre to the area of the Black Sea, the largest meromictic basin (Pimenov and Neretin, 2006). While chemocline is present in all meromictic basins, the density (abundance) of the microbial community may vary widely. Lake Mahoney (Canada), one of the lakes best studied from the microbiological point of view, probably has the highest density of the chemocline community. Abundance of purple sulfur bacteria in its dense layer was shown to exceed $10^{8}$ cells $\mathrm{mL}^{-1}$ (Overmann, 1997). Metagenomic analysis of the community of the bacterial plate in the chemocline layer revealed purple sulfur bacteria of the genus Thiohalocapsa (family Chromatiaceae) to be the main primary producers (Hamilton et al., 2014). In Lake Khruslomeny, this function was performed by green sulfur bacteria Chlorobium phaeovibrioides, which was probably due to the differences in water composition between these two lakes. Lake Mahoney is saline and alkaline, with the salt content of its water differing from that of seawater.

A meromictic Lake Suigetsu (Wakasa Bay, Sea of Japan) is similar to the basins of the Kandalaksha Bay coast. This lake has a limited connection to the sea bay. Analysis of the pigments from Lake Suigetsu water column revealed predominance of bacteriochlorophyll $e$, originating from brown-colored green sulfur bacteria (Kondo et al., 2014). The numbers of phototrophic bacteria in the chemocline exceeded $5 \times 10^{6}$ cells $\mathrm{mL}^{-1}$ (June). Analysis by quantitative real-time PCR revealed that green sulfur bacteria Chl. phaeovibrioides, Chl. limicola, and Chl. luteolum were predominant in the chemocline microbial community (Mori et al., 2013). This is an indication of the similarity between microbial communities of the lakes Suigetsu and B. Khruslomeny.

A meromictic Lake Nitinat (British Columbia, Canada), located in a fjord bed (Schmidtova et al., 2009), is geochemically similar to Lake B. Khruslomeny. Location of its chemocline (transition zone) depends on the season. In April, Chlorobium 
species dominated the chemocline library, including two highly represented clusters: one related to the environmental clone Chlorobium sp. Mog 4 (EF149015) from Lake Mogilnoe (Lunina et al., 2005) and the other related to Chl. phaeobacteriodes BS1 (CP001101) isolated from the Black Sea chemocline (Manske et al., 2005) Chlorobium species were accompanied by epsilonproteobacteria most closely related to thiotrophic endosymbionts of marine invertebrates, as well as by Arcobacter sp., which was capable of growth at high sulfide concentrations and traces of oxygen $(1-10 \mu \mathrm{M})$. Two sequences were related to a methanotrophic endosymbiont of Bathymodiolus sp., and several others also clustered together within the Methylococcales (Schmidtova et al., 2009).

The meromictic Clipperton lagoon is located in the tropical Pacific, to the southwest from the Mexican coast. The lagoon became separated from the ocean $\sim 160$ years ago. Its greatest depth is $45 \mathrm{~m}$, and it has a classical meromictic profile of the water column, with a saltish mixolimnion and an anoxic monimolimnion at almost marine salinity, which are separated by the chemocline at $13-18 \mathrm{~m}$. Green sulfur bacteria (Chlorobi) predominated in the chemocline microbial community, with their numbers up to $6 \times 10^{6}$ cells $\mathrm{mL}^{-1}$. Only two different genera of green sulfur bacteria were predominant in the libraries: Prosthecochloris and Chlorobium. Analysis of the pmoA functional gene in the pycnocline revealed occurrence of methanotrophs (genera Methylomonas and Methylococcus). The gene indicative of sulfate reduction, $d s r A B$, could only be amplified from the pycnocline. All sequences belonged to the Deltaproteobacteria. The $d s r A B$ genes were not detected in the monimolimnion, even though the $16 \mathrm{~S}$ rRNA gene sequences from typical sulfate-reducing Deltaproteobacteria were present.

In the relic Lake Mogilnoe (Kildin Island, Barents Sea), which is also connected to the sea, anoxygenic green phototrophic bacteria Chl. phaeovibrioides, Pelodictyon phaeum, and Prosthecochloris phaeoasteroidea formed the backbone of the chemocline microbial community. Purple sulfur bacteria Thiocapsa roseopersicina and Thiocystis gelatinosa were the minor components (Lunina et al., 2005).

The present work dealt with a meromictic lake recently separated from a sea bay and retaining the salt composition similar to that of seawater. Similar to Lake B. Khruslomeny, in Lake Trekhtsvetnoe, the subject of our previous study, the phototrophic community of the dense layer was represented exclusively by green sulfur bacteria Chl. phaeovibrioides (Savvichev et al., 2018). The numbers of these microorganisms in this narrow layer (bacterial plate were as high as $2.1 \times 10^{7}$ cells $\mathrm{mL}^{-1}$.

Among the Kandalaksha Bay coastal basins with limited connection to the sea, Lake B. Khruslomeny is characterized by its stable hydrological regime. Its stable stratification is probably the factor responsible for formation of the dense green layer. Lake B. Khruslomeny chemocline is characterized by the evident predominance of Chl. phaeovibrioides, extremely high rate of anoxygenic photosynthesis (up to $34.5 \mu \mathrm{mol} \mathrm{C} \mathrm{L}^{-1}$ day $^{-1}$ ), high rate of light-stimulated methane oxidation (up to $170 \mathrm{nmol} \mathrm{CH}_{4}$ $\mathrm{L}^{-1}$ day $^{-1}$ ), and occurrence of Synechocystis cyanobacteria and Methyloprofundus methanotrophic gammaproteobacteria.
Methane content in the Lake B. Khruslomeny monimolimnion (from 1.68 to $1.82 \mathrm{mmol} \mathrm{CH}_{4} \mathrm{~L}^{-1}$; Figure 6) was stable and very high, comparable to the values for the known meromictic basins: deep-water Lake Matano in Indonesia (Crowe et al., 2008), Lake Kivu in Eastern Africa (Schmid et al., 2005), and Lake Pavin in France (Lehours et al., 2005). Considering the total depth of the lake, the calculated methane content in the water column was $12.5 \mathrm{~mol} \mathrm{CH}_{4} \mathrm{~m}^{-2}$ in September and $12.2 \mathrm{~mol}$ $\mathrm{CH}_{4} \mathrm{~m}^{-2}$ in March. Over $99 \%$ of methane was concentrated in the monimolimnion. Methane was most actively consumed in the chemocline at the rate of up to $175 \mathrm{nmol} \mathrm{CH}_{4} \mathrm{~L}^{-1}$ day $^{-1}$ (September).

In September, methane oxidation was most intense in the narrow depth interval from 3.75 to $4.0 \mathrm{~m}$; no noticeable stimulation of this process by light was observed there. The zone where light-dependent methane oxidation occurred was at the lowermost horizon where oxygen measurement was possible. Methanotrophic gammaproteobacteria of the family Methylococcaceae were detected in the same depth interval. In this horizon $(3.75 \mathrm{~m})$, cyanobacteria of the order Synechococcales were also revealed; moreover, the share of their 16S rRNA gene sequences $(2.5-3 \%)$ was close to that of methanotrophs. The results of radiotracer studies and molecular analysis indicated light-dependent methane oxidation, which was most probably carried out by methanotrophic gammaproteobacteria in association with cyanobacteria, which provide oxygen for this process (Savvichev et al., 2018). According to the equation $\mathrm{CH}_{4}+2 \mathrm{O}_{2}=\mathrm{CO}_{2}+2 \mathrm{H}_{2} \mathrm{O}$, the calculated oxygen requirement for $\mathrm{MO}$ at 3.75 and $4.0 \mathrm{~m}$ is 0.35 and $0.11 \mu \mathrm{mol} \mathrm{O}_{2} \mathrm{~L}^{-1}$ day $^{-1}$, respectively. The calculated oxygen production via oxygenic photosynthesis $\left(\mathrm{CO}_{2}+\mathrm{H}_{2} \mathrm{O}=\mathrm{CH}_{2} \mathrm{O}+\mathrm{O}_{2}\right)$ is 1.18 and $0.40 \mu \mathrm{mol} \mathrm{O}_{2} \mathrm{~L}^{-1}$ day $^{-1}$ at 3.75 and $4.0 \mathrm{~m}$, respectively. This is sufficient for methane oxidation. Results of such calculations should, be treated with caution, since, apart from methane, oxygen may react with other reduced compounds.

Light-dependent methane oxidation has been previously reported only for freshwater meromictic lakes from diverse climatic zones (Milucka et al., 2015; Oswald et al., 2015, Oswald et al., 2016; Kallistova et al., 2019), where methanotrophic gammaproteobacteria were detected in the presence of analytically measurable oxygen concentrations. In the chemocline of Lake B. Khruslomeny salinity was approximately one-third of that of seawater. Therefore, while methanotrophs of the genus İethylobacter predominate in freshwater continental meromictic lakes (Kallistova et al., 2019), typical marine methane-oxidizers of the genus Methyloprofundus prevailed in the Lake B. Khruslomeny chemocline in September. The composition of the hypolimnion water column of the lake was of the marine type. During winter, aerobic methanotrophs (both Methyloprofundus and freshwater Methylobacter) were revealed mainly in the upper oxic layer $(0.5-1.5 \mathrm{~m})$, above the chemocline, where cyanobacteria were also present $(\sim 1 \%)$. Thus, methane oxidation occurred in winter mainly in the upper oxic zone, rather than in the chemocline, and was less dependent on activity of cyanobacteria. High numbers of chemolithotrophic sulfur-oxidizing bacteria of the genera Thiomicrorhabdus and 
Sulfurimonas were also present in the chemocline and upper horizons during winter. Lower illumination and photosynthetic activity in winter probably prevented Chl. phaeovibrioides from utilizing all sulfide produced by sulfate reducers, so other sulfur oxidizers could develop as well.

In the presence of dissolved sulfate, the possibility of sulfate-dependent methane oxidation in the anoxic water column could not be ruled out. However, no 16S rRNA gene sequences typical of ANME archaea were detected. Likewise, the NC10 bacteria oxidizing methane with nitrite were also not detected in the chemocline or hypolimnion. Thus, the present work shows that light-dependent methane oxidation is not restricted to continental freshwater stratified lakes, but may contribute significantly to the oxidation of this important greenhouse gas in the sea coastal reservoirs, which were separated from the major marine basin, but retained partial connection to it.

Lake B. Khruslomeny is a lake where microorganisms formed a complex community with predominance of Chlorobi green sulfur bacteria in the chemocline, which was capable of efficient utilization of reduced compounds (sulfide and methane) on their way from the bottom sediments to the surface.

Interestingly, one-third to a half of the microorganisms from the oxic zone belonged to uncultured bacterial and archaeal lineages, the superphyla Patescibacteria and DPANN, with Woesearchaeota constituting the major share of all uncultured groups. These two microbial groups both have small cells $(<1 \mu \mathrm{m})$ and small genomes; they are considered to possess limited metabolic abilities, to be incapable of oxidative metabolism, and to lack a number of pathways for biosynthesis of the key cell components, which may indicate their partnerdependent (symbiotic or parasitic) lifestyle (Castelle et al., 2015, 2018). Particularly, recent abundance distribution and cooccurrence network analyses across diverse biotopes suggested a potential syntrophic relationship between Woesearchaeota and methanogens (Liu et al., 2018). However, the share of methanogenic archaea in Lake B. Khruslomeny is low, and their distribution with depth differs from that of Woesearchaeota. High occurrence of DPANN archaea, especially Woesearchaeota, in freshwater lakes has been reported in several studies (e.g., Bowman et al., 2013; Kallistova et al., 2019). Abundance of these organisms indicates that they may play an important ecological role. Thus, it was recently shown that Woesearchaeota and Patescibacteria form an important part of the proteindegrading microbial communities in the Black Sea anoxic waters (Suominen et al., 2019). Moreover, due to a higher ratio of surface

\section{REFERENCES}

Alonso-Saez, L., Galand, P. E., Casamayor, E. O., Alio, C. P., and Bertilsson, S. (2010). High bicarbonate assimilation in the dark by Arctic bacteria. ISME J. 4, 1581-1590. doi: 10.1038/ismej.2010.69

Bastviken, D., Cole, J. J., Pace, M. L., and Van de Bogert, M. C. (2008). Fates of methane from different lake habitats: connecting whole-lake budgets and CH4 emissions. J. Geophys. Res. Biogeosci. 2008. 113, G02024. doi: 10.1029/ 2007JG000608

Blees, J., Niemann, H., Wenk, C. B., Zopfi, J., Schubert, C. J., Kirf, M., et al. (2014). Micro-aerobic bacterial methane oxidation in the chemocline and anoxic water column of deep south Alpine Lake Lugano area to volume, small cell size facilitates nutrient uptake and increases the metabolic rate (Savage et al., 2007). Therefore the role of scavengers efficiently utilizing organic compounds and metabolites could be proposed for Patescibacteria and DPANN in the Lake B. Khruslomeny.

\section{DATA AVAILABILITY STATEMENT}

The 16S rRNA gene sequences were deposited in the Sequence Read Archive (SRA) via the National Center for Biotechnology Information (NCBI) under accession nos. SRR11816416SRR11816441.

\section{AUTHOR CONTRIBUTIONS}

AS, NR and NP contributed to the conception and design of the study. AS, VK, IR, EK, DV, NK, GL, ND, and NB participated in field research and initial treatment of the materials. $\mathrm{VK}, \mathrm{AB}$, $\mathrm{AM}$, and NR carried out molecular ecological and bioinformatic analysis. AK and PS contributed to the writing and editing of the manuscript. All authors contributed to the article and approved the submitted version.

\section{FUNDING}

The expedition and primary research were supported by the Russian Foundation for Basic Research, project 19-05-00377. Radiotracer studies were supported by the Russian Foundation for Basic Research, project 20-04-00487. Investigation of the processes of the methane and sulfur cycles and of the composition of the microbial community was supported by the Russian Science Foundation, project 16-14-10201, as well as by the Ministry of Science and Higher Education of the Russian Federation.

\section{ACKNOWLEDGMENTS}

The authors are grateful to A. B. Tsetlin (White Sea Biological Station, Moscow State University) for their help in field research and to their colleagues from other institutions for their participation in the winter and summer research on Lake B. Khruslomeny.

(Switzerland). Limnol. Oceanogr. 59, 311-324. doi: 10.4319/lo.2014.59. 2.0311

Boden, R., Scott, K. M., Rae, A. W., and Hutt, L. P. (2017). Reclassification of Thiomicrospira hydrogeniphila (Watsuji et al. 2016) to Thiomicrorhabdus hydrogenophila comb. nov., with emended description of Thiomicrorhabdus (Boden et al., 2017). Int. J. Syst. Evol. Microbiol. 67, 4205-4209. doi: 10.1099/ ijsem.0.002279

Boetius, A. (2019). Global change microbiology-big questions about small life for our future. Nat. Rev. Microbiol. 17, 331-332. doi: 10.1038/s41579-0190197-2

Bowman, J. S., Larose, C., Vogel, T. M., and Deming, J. W. (2013). Selective occurrence of Rhizobiales in frost flowers on the surface of young sea ice near 
Barrow, Alaska and distribution in the polar marine rare biosphere. Environ. Microbiol. Rep. 5, 575-582. doi: 10.1111/1758-2229.12047

Brand, A., Bruderer, H., Oswald, K., Guggenheim, C., Schubert, C. J., and Wehrli, B. (2016). Oxygenic primary production below the oxycline and its importance for redox dynamics. Aquat. Sci. 78, 727-741. doi: 10.1007/s00027-016-0465-4

Brown, C. T., Hug, L. A., Thomas, B. C., Sharon, I., Castelle, C. J., Singh, A., et al. (2015). Unusual biology across a group comprising more than $15 \%$ of domain Bacteria. Nature 23, 208-211. doi: 10.1038/nature14486

Camacho, A., Erez, J., Chicote, A., Florin, M., Squires, M. M., Lehmann, C., et al. (2001). Microbial microstratification, inorganic carbon photoassimilation and dark carbon fixation at the chemocline of the meromictic Lake Cadagno (Switzerland) and its relevance to the food web. Aquat. Sci. 2001, 91-106. doi: $10.1007 / \mathrm{pl} 100001346$

Canfield, D. E., Jorgensen, B. B., Fossing, H., Glud, R., Gundersen, J., Ramsing, N. B., et al. (1993). Pathways of organic-carbon oxidation in 3 continental margin sediments. Mar. Geol. 113, 27-40. doi: 10.1016/0025-3227(93)90147-n

Carnevali, P. B. M., Herbold, C. W., Hand, K. P., Priscu, J. C., and Murray, A. E. (2018). Distinct microbial assemblage structure and archaeal diversity in sediments of arctic thermokarst lakes differing in methane sources. Front. Microbiol. 9:1192. doi: 10.3389/fmicb.2018.01192

Castelle, C. J., Brown, C. T., Anantharaman, K., Probst, A. J., Huang, R. H., and Banfield, J. F. (2018). Biosynthetic capacity, metabolic variety and unusual biology in the CPR and DPANN radiations. Nat. Rev. Microbiol. 16, 629-645. doi: 10.1038/s41579-018-0076-2

Castelle, C. J., Wrighton, K. C., Thomas, B. C., Hug, L. A., Brown, C. T., Wilkins, M. J., et al. (2015). Genomic expansion of domain archaea highlights roles for organisms from new phyla in anaerobic carbon cycling. Curr. Biol. 25, 690-701. doi: 10.1016/j.cub.2015.01.014

Craig, H. (1957). Isotopic standards for carbon and oxygen and correction factors for mass spectrometric analysis carbon dioxide. Geochim. Cosmochim. Acta. 12, 133-149. doi: 10.1016/0016-7037(57)90024-8

Crowe, S. A., Katsev, S., Leslie, K., Sturm, A., Magen, C., Nomosatrio, S., et al. (2010). The methane cycle in ferruginous lake Matano. Geobiology 9, 61-78. doi: $10.1111 / j .1472-4669.2010 .00257 . x$

Crowe, S. A., Maresca, J. A., Jones, C., Sturm, A., Henny, C., and Fowle, D. A. (2014). Deep-water anoxygenic photosynthesis in a ferruginous chemocline. Geobiology 12, 322-339. doi: 10.1111/gbi.12089

Crowe, S. A., O’Neill, A. H., Katsev, S., Hehanussa, P., Haffner, G. D., Sundby, B., et al. (2008). The biogeochemistry of tropical lakes: a case study from Lake Matano. Indonesia. Limnol. Oceanogr. 53, 319-331. doi: 10.4319/lo.2008.53.1. 0319

Dyksma, S., and Gallert, C. (2019). Candidatus Syntrophosphaera thermopropionivorans: a novel player in syntrophic propionate oxidation during anaerobic digestion. Environ. Microbiol. Rep. 11, 558-570. doi: 10.1111/ $1758-2229.12759$

Edgar, R. C. (2010). Search and clustering orders of magnitude faster than BLAST. Bioinformatics 26, 2460-2461. doi: 10.1093/bioinformatics/btq461

Eller, G., Kanel, L., and Kruger, M. (2005). Cooccurrence of aerobic and anaerobic methane oxidation in the water column of Lake Plußsee. Appl. Environ. Microbiol. 71, 8925-8928. doi: 10.1128/AEM.71.12.8925-8928.2005

Elshahed, M. S., and McInerney, M. J. (2001). Benzoate fermentation by the anaerobic bacterium Syntrophus aciditrophicus in the absence of hydrogenusing microorganisms. Appl. Environ. Microbiol. 67, 5520-5525. doi: 10.1128/ aem.67.12.5520-5525.2001

Galand, P. E., Bourrain, M., De Maistre, E., Catala, P., Desdevises, Y., Elifantz, H., et al. (2012). Phylogenetic and functional diversity of Bacteria and Archaea in a unique stratified lagoon, the Clipperton atoll (N Pacific). FEMS Microbiol. Ecol. 79, 203-217. doi: 10.1111/j.1574-6941.2011.01209.x

Garcia-Gil, L. J., Vicente, E., Camacho, A., Borrego, C. M., Vila, X., Cristina, X. P., et al. (1999). Vertical distribution of photosynthetic sulphur bacteria linked to saline gradients in Lake El Tobar (Cuenca. Spain). Aquat. Microb. Ecol. 20, 299-303. doi: 10.3354/ame020299

Gibson, C. E. (1985). Growth-rate, maintenance energy and pigmentation of planktonic cyanophyta during one-hour light-dark cycles. Brit. Phycol. J. 20, 155-161. doi: 10.1080/00071618500650161

Giovannoni, S. J. (2017). SAR11 bacteria: the most abundant plankton in the oceans. Annu. Rev. Mar. Sci. 9, 231-255. doi: 10.1146/annurev-marine010814-015934
Hamilton, T. L., Bovee, R. J., Thiel, V., Sattin, S. R., Mohr, W., Schaperdoth, I., et al. (2014). Coupled reductive and oxidative sulfur cycling in the phototrophic plate of a meromictic lake. Geobiology 12, 451-468. doi: 10.1111/gbi. 12092

Hobbie, J. T., Daley, R. J., and Jasper, S. (1977). Use of Nucleopore filters for counting bacteria by fluorescence microscopy. Appl. Environ. Microbiol. 33, 1225-1228. doi: 10.1128/aem.33.5.1225-1228.1977

Holmström, C., and Kjelleberg, S. (1999). Marine Pseudoalteromonas species are associated with higher organisms and produce biologically active extracellular agents. FEMS Microbiol. Ecol. 30, 285-293. doi: 10.1016/s0168-6496(99) 00063-x

Ivanov, M. V., Rusanov, I. I., Pimenov, N. V., Bairamov, I. T., Yusupov, S. K., Savvichev, A. S., et al. (2001). Microbial processes of the carbon and sulfur cycles in Lake Mogil'noe. Microbiology 70, 583-594.

Jiang, F., Li, W. J., Xiao, M. C., Dai, J., Kan, W. J., Chen, L., et al. (2012). Luteolibacter luojiensis sp nov., isolated from Arctic tundra soil, and emended description of the genus Luteolibacter. Int. J. Syst. Evol. Microbiol. 62, 22592263. doi: 10.1099/ijs.0.037309-0

Jochum, L. M., Schreiber, L., Marshall, I. P., Jørgensen, B. B., Schramm, A., and Kjeldsen, K. U. (2018). Single-cell genomics reveals a diverse metabolic potential of uncultivated Desulfatiglans-related Deltaproteobacteria widely distributed in marine sediment. Front. Microbiol. 9:2038. doi: 10.3389/fmicb. 2018.02038

Kadnikov, V. V., Savvichev, A. S., Mardanov, A. V., Beletsky, A. V., Ravin, N. V., and Pimenov, N. V. (2019a). Metagenomic data of the microbial community of the chemocline layer of the meromictic subarctic Lake Bolshie Hruslomeny, North European Russia. Data Brief. Mar. 2:103800. doi: 10.1016/j.dib.2019. 103800

Kadnikov, V. V., Savvichev, A. S., Mardanov, A. V., Beletsky, A. V., Merkel, A. Y., Ravin, N. V., et al. (2019b). Microbial communities involved in the methane cycle in the near-bottom water layer and sediments of the meromictic subarctic Lake Svetloe. Antonie Van Leeuwenhoek 112, 1801-1814. doi: 10.1007/s10482019-01308-1

Kallistova, A., Kadnikov, V., Rusanov, I., Kokryatskaya, N., Beletsky, F., Mardanov, A., et al. (2018). Microbial communities involved in aerobic and anaerobic methane cycling in a meromictic ferruginous subarctic lake. Aquat. Microb. Ecol. 82, 1-18. doi: 10.3354/ame 01878

Kallistova, A., Montonen, L., Jurgens, G., Münster, U., Kevbrina, M., and Nozhevnikova, A. (2014). Culturable psychrotolerant methanotrophic bacteria in landfill cover soil. Microbiology 82, 847-855. doi: 10.1134/ S0026261714010044

Kallistova, A. Yu., Savvichev, A. S., Rusanov, I. I., and Pimenov, N. V. (2019). Thermokarst Lakes, Ecosystems with Intense Microbial Processes of the Methane Cycle. Microbiology 88, 649-661.

Kang, I., Lee, K., Yang, S.-J., Choi, A., Kang, D., Lee, Y. K., et al. (2012). Genome sequence of "Candidatus aquiluna" sp. strain IMCC13023, a marine member of the Actinobacteria isolated from an Arctic fjord. J. Bacteriol. 194, 3550-3551. doi: 10.1128/jb.00586-12

Kasalický, V., Zeng, Y., Piwosz, K., Šimek, K., Kratochvilová, H., and Kobližek, M. (2018). Aerobic anoxygenic photosynthesis is commonly present within the genus Limnohabitans. Appl. Environ. Microbiol. 84, e2116-e2117.

Knittel, K., and Boetius, A. (2009). Anaerobic oxidation of methane: progress with an unknown process. Annu. Rev. Microbiol. 63, 311-334. doi: 10.1146/annurev. micro.61.080706.093130

Koeksoy, E., Halama, M., Konhauser, K. O., and Kappler, A. (2016). Using modern ferruginous habitats to interpret precambrian banded iron formation deposition. Int. J. Astrobiol. 15, 205-217. doi: 10.1017/s1473550415000373

Kondo, R., Kodera, M., Mori, Y., Okamura, T., Yoshikawa, S., and Ohki, K. (2014). Spatiotemporal distribution of bacteriochlorophylls in the meromictic Lake Suigetsu. Japan. Limnology 15, 77-83. doi: 10.1007/s10201-013-0415-y

Krasnova, E., Voronov, D., Frolova, N., Pantyulin, A., and Samsonov, T. (2015). Salt lakes separated from the White Sea as an object of research using remote sensing methods. EARSeL eProc. 14, 8-22.

Krasnova, E. D., Pantyulin, A. N., Matorin, D. N., Todorenko, D. A., Belevich, T. A., Milyutina, I. A., et al. (2014). Cryptomonad alga Rhodomonas sp. (Cryptophyta, Pyrenomonadaceae) bloom in the redox zone of the basins separating from the White Sea. Microbiology 83, 270-277. doi: 10.1134/s0026261714030102 
Kuznetsov, S. I. (1970). Microflora of Lakes and Its Geochemical Activity. Leningrad: Nauka.

Lambrecht, N., Katsev, S., Wittkop, C., Hall, S. J., Sheik, C. S., Picard, A., et al. (2019). Biogeochemical and physical controls on methane fluxes from two ferruginous meromictic lakes. Geobiology 18, 54-69. doi: 10.1111/gbi.12365

Lee, J., Park, B., Woo, S. G., Lee, J., and Park, J. (2014). Prosthecobacter algae sp. nov., isolated from activated sludge using algal metabolites. Int. J. Syst. Evol. Microbiol. 64, 663-667. doi: 10.1099/ijs.0.052787-0

Legendre, L., Demers, S., Clurice, M., Yentsch, C. M., and Yentsch, C. S. (1983). The 14C method: patterns of dark CO2 fixation and DCMU correction to replace the dark bottle. Limnol. Oceanogr. 28, 996-1003. doi: 10.4319/lo.1983.28.5. 0996

Lehours, A. C., Bardot, C., Thenot, A., Debroas, D., and Fonty, G. (2005). Anaerobic microbial communities in Lake Pavin, a unique meromictic lake in France. Appl. Environ. Microbiol. 71, 7389-7400. doi: 10.1128/aem.71.11.73897400.2005

Li, C., Lai, Q., Li, G., Dong, C., Wang, J., Liao, Y., et al. (2014). Hyphomonas beringensis sp. nov. and Hyphomonas chukchiensis sp. nov., isolated from surface seawater of the Bering Sea and Chukchi Sea. Antonie Van Leeuwenhoek 106, 657-665. doi: 10.1007/s10482-014-0236-y

Limam, R. D., Chouari, R., Mazeas, L., Wu, T. D., Li, T., Grossin-Debattista, J., et al. (2014). Members of the uncultured bacterial candidate division WWE 1 are implicated in anaerobic digestion of cellulose. MicrobiologyOpen. 3, 157-167. doi: $10.1002 / \mathrm{mbo} 3.144$

Liu, X., Li, M., Castelle, C. J., Probst, A. J., Zhou, Z., Pan, J., et al. (2018). Insights into the ecology, evolution, and metabolism of the widespread Woesearchaeotal lineages. Microbiome 6:102.

Lunina, O. N., Gorlenko, V. M., Solov'eva, O. A., Akimov, V. N., Rusanov, I. I., and Pimenov, N. V. (2005). Seasonal changes in the structure of the anoxygenic phototrophic bacterial community in Lake Mogilnoe, a relict lake on Kil'din Island in the Barents Sea. Microbiology 74, 588-596. doi: 10.1007/s11021-005$0107-7$

Lunina, O. N., Savvichev, A. S., Pimenov, N. V., Kuznetsov, B. B., and Gorlenko, V. M. (2013). Anoxygenic phototrophic bacteria of the Lake Kislo-Sladkoe (Kandalaksha Bay of the White Sea). Microbiology 82, 815-832. doi: 10.1134/ s0026261714010081

Lyman, J., and Fleming, R. H. (1940). Composition of sea water. J. Marine Res. 3, 134-139.

Manske, A. K., Glaeser, J., Kuypers, M. M. M., and Overmann, J. (2005). Physiology and phylogeny of green sulfur bacteria forming a monospecific phototrophic assemblage at a depth of 100 meters in the Black Sea. Appl. Environ. Microbiol. 71, 8049-8060. doi: 10.1128/aem.71.12.8049-8060.2005

McAuliffe, C. (1971). Gas chromatographic determination of solutes by multiple phase equilibrium. Chem. Technol. 1, 46-51.

McInerney, M. J., Rohlin, L., Mouttaki, H., Kim, U., Krupp, R. S., Rios-Hernandez, L., et al. (2007). The genome of Syntrophus aciditrophicus: life at the thermodynamic limit of microbial growth. Proc. Natl. Acad. Sci. U.S.A. 104, 7600-7605. doi: 10.1073/pnas.0610456104

Milucka, J., Kirf, M., Lu, L., Krupke, A., Lam, P., Littmann, S., et al. (2015). Methane oxidation coupled to oxygenic photosynthesis in anoxic waters. ISME J. 9, 1991-2002. doi: 10.1038/ismej.2015.12

Mori, Y., Kataoka, T., Okamura, N., and Kondo, R. (2013). Dominance of green sulfur bacteria in the chemocline of the meromictic Lake Suigetsu, Japan, as revealed by dissimilatory sulfite reductase gene analysis. Arch. Microbiol. 195, 303-312. doi: 10.1007/s00203-013-0879-5

Nobu, M. K., Narihiro, T., Rinke, C., Kamagata, Y., Tringe, S. G., Woyke, T., et al. (2015). Microbial dark matter ecogenomics reveals complex synergistic networks in a methanogenic bioreactor. ISME J. 9, 1710-1722. doi: 10.1038/ ismej.2014.256

Ohshiro, T., Harada, N., Kobayashi, Y., Miki, Y., and Kawamoto, H. (2012). Microbial fucoidan degradation by Luteolibacter algae $\mathrm{H} 18$ with deacetylation. Biosci. Biotechnol. Biochem. 76, 620-623. doi: 10.1271/bbb.110911

Ortiz-Alvarez, R., and Casamayor, E. O. (2016). High occurrence of Pacearchaeota and Woesearchaeota (Archaea superphylum DPANN) in the surface waters of oligotrophic high-altitude lakes. Environ. Microbiol. Rep. 8, 210-217. doi: 10.1111/1758-2229.12370

Oswald, K., Jegge, C., Tischer, J. Berg, J., Brand, A., Miracle, M. R., et al. (2016). Methanotrophy under versatile conditions in the water column of the ferruginous meromictic Lake La Cruz (Spain). Front. Microbiol. 7:1762. doi: 10.3389/fmicb.2016.01762

Oswald, K., Milucka, J., Brand, A., Littmann, S., Wehrli, B., Kuypers, M. M. M., et al. (2015). Light-dependent aerobic methane oxidation reduces methane emissions from seasonally stratified lakes. PLoS One 10:e0132574. doi: 10.1371/ journal.pone. 0132574

Overmann, J. (1997). Mahoney Lake: a case study of the ecological significance of phototrophic sulphur bacteria. Adv. Microb. Ecol. 15, 251-288. doi: 10.1007/ 978-1-4757-9074-0_6

Overmann, J., Beatty, J. T., Hall, K. J., Pfennig, N., and Northcote, T. G. (1991). Characterization of a dense, purple sulfur bacterial layer in a meromictic salt lake. Limnol. Oceanogr. 36, 846-859. doi: 10.4319/lo.1991.36.5.0846

Parrilli, E., Tedesco, P., Fondi, M., Tutino, M. L., Giudice, A. L., de Pascale, D., et al. (2019). The art of adapting to extreme environments: the model system Pseudoalteromonas. Phys. Life Rev. doi: 10.1016/j.plrev.2019.04.003 [Epub ahead of print].

Pelletier, E., Kreymeyer, A., Bocs, S., Rouy, Z., Gyapay, G., Chouari, R., et al. (2008). "Candidatus Cloacamonas acidaminovorans": genome sequence reconstruction provides a first glimpse of a new bacterial division. J. Bacteriol. 190, 2572-2579. doi: 10.1128/JB.01248-07

Pimenov, N. V., and Neretin, L. N. (2006). "Composition and activities of microbial communities involved in carbon, sulfur, nitrogen and manganese cycling in oxic/anoxic interface of the Black Sea," in Past and Present Water Column Anoxia. Nato Science Series: IV: Earth and Environmental Sciences, ed. L. N. Neretin (Dordrecht: Springer), 501-521. doi: 10.1007/1-4020-4297-3_19

Pimenov, N. V., Rusanov, I. I, Karnachuk, O. V., Rogozin, D. Yu, Bryantseva, I. A., Lunina, O. N., et al. (2003). Microbial processes of the carbon and sulfur cycles in Lake Shira (Khakasia). Microbiology 72, 221-229.

Pruesse, E., Peplies, J., and Glockner, F. O. (2012). SINA: accurate high-throughput multiple sequence alignment of ribosomal RNA genes. Bioinformatics 28, 18231829. doi: 10.1093/bioinformatics/bts 252

Quast, C., Pruesse, E., Yilmaz, P., Gerken, J., Schweer, T., Yarza, P., et al. (2013). The SILVA ribosomal RNA gene database project: improved data processing and web-based tools. Nucleic Acids Res. 41, D590D596.

Raven, J. A., Kubler, J. E., and Beardall, J. (2000). Put out the light, and then put out the light. J. Mar. Biol. Assoc. U. K. 80, 1-25. doi: 10.1017/S0025315499001526

Reeburgh, W. S. (2007). Oceanic methane biogeochemistry. Chem. Rev. 107, 486-513. doi: $10.1021 / \mathrm{cr} 050362 \mathrm{v}$

Restrepo-Ortiz, C. X., and Casamayor, E. O. (2013). Environmental distribution of two widespread uncultured freshwater Euryarchaeota clades unveiled by specific primers and quantitative PCR. Environ. Microbiol. Rep. 5, 861-867. doi: $10.1111 / 1758-2229.12088$

Rinke, C., Schwientek, P., Sczyrba, A., Ivanova, N. N., Anderson, I. J., Cheng, J. F., et al. (2013). Insights into the phylogeny and coding potential of microbial dark matter. Nature 499, 431-437. doi: 10.1038/nature1 2352

Rogozin, D. Y., Tarnovsky, M. O., Belolipetskii, V. M., Zykov, V. V., Zadereev, E. S., Tolomeev, A. P., et al. (2017). Disturbance of meromixis in saline Lake Shira (Siberia, Russia): possible reasons and ecosystem response. Limnologica 66, 12-23. doi: 10.1016/j.limno.2017.06.004

Rogozin, D. Y., Trusova, M. Y., Khromechek, E. B., and Degermendzhi, A. G. (2010). Microbial community of the chemocline of the meromictic Lake Shunet (Khakassia, Russia) during summer stratification. Microbiology 79, 253-261. doi: 10.1134/s0026261710020189

Savage, V. M., Allen, A. P., Brown, J. H., Gillooly, J. F., Herman, A. B., Woodruff, W. H., et al. (2007). Scaling of number, size, and metabolic rate of cells with body size in mammals. Proc. Natl. Acad. Sci. U.S.A. 104, 4718-4723. doi: 10.1073/pnas.0611235104

Savvichev, A. S., Babenko, V. V., Lunina, O. N., Letarova, M. A., Boldyreva, D. I., Weslopolova, E. F., et al. (2018). Sharp water column stratification with an extremely dense microbial population in a small meromictic lake Trekhtzetnoe separated from the White Sea. Environ. Microbiol. 20, 3784-3797. doi: 10.1111/ 1462-2920.14384

Savvichev, A. S., Demidenko, N. A., Krasnova, E. D., Kalmatskaya, O. V., Kharcheva, A. N., and Ivanov, M. V. (2017). Microbial processes in the Kanda bay, a meromictic water body artifically separated from the White Sea. Doklady Biol. Sci. 474, 135-139. doi: 10.1134/s0012496617030103 
Savvichev, A. S., Kadnikov, V. V., Kallistova, A. Y., Rusanov, I. I, Voronov, D. A., Krasnova, E. D., et al. (2019). Light-dependent methane oxidation is the major process of the methane cycle in the water column of the Bol'shie Khruslomeny polar lake. Microbiology 88, 370-374. doi: 10.1134/S00262617190 3010X

Savvichev, A. S., Lunina, O. N., Rusanov, I. I., Zakharova, E. E., Veslopolova, E. F., and Ivanov, M. V. (2014). Microbiological and isotopic geochemical investigation of Lake Kislo-Sladkoe, the meromictic water body at the Kandalaksha Bay Shore (White Sea). Microbiology 83, 56-66. doi: 10.1134/ s0026261714010111

Savvichev, A. S., Rusanov, I. I, Yusupov, S. K., Pimenov, N. V., Lein, A. Y., and Ivanov, M. V. (2004). The biogeochemical cycle of methane in the coastal zone and littoral of the Kandalaksha Bay of the White Sea. Microbiology 73, 457-469.

Schloss, P. D., Westcott, S. L., Ryabin, T., Hall, J. R., Hartmann, M., Hollister, E. B., et al. (2009). Introducing mothur: open-source, platform-independent, community-supported software for describing and comparing microbial communities. Appl. Environ. Microbiol. 75, 7537-7741.

Schmid, M., Halbwachs, M., Wehrli, B., and Wuest, A. (2005). Weak mixing in Lake Kivu: new insights indicate increasing risk of uncontrolled gas eruption. Geochem. Geophys. Geosyst. 6:Q07009. doi: 10.1029/2004GC000892

Schmidtova, J., Hallam, S. J., and Baldwin, S. A. (2009). Phylogenetic diversity of transition and anoxic zone bacterial communities within a near-shore anoxic basin: Nitinat Lake. Environ. Microbiol. 11, 3233-3251. doi: 10.1111/j.14622920.2009.02044.x

Schubert, C. J., Lucas, F. S., Durisch-Kaiser, E., Stierli, R., Diem, T., Scheidegger, O., et al. (2010). Oxidation and emission of methane in a monomictic lake (Rotsee. Switzerland). Aquat. Sci. 72, 455-466. doi: 10.1007/s00027-010-0148-5

Singh, B. K., Bardgett, R. D., Smith, P., and Reay, D. S. (2010). Microorganisms and climate change?: terrestrial feedbacks and mitigation options. Nat. Rev. Microbiol. 8, 779-790. doi: 10.1038/nrmicro2439

Solli, L., Håvelsrud, O. E., Horn, S. J., and Rike, A. G. (2014). A metagenomic study of the microbial communities in four parallel biogas reactors. Biotechnol. Biofuels 7:146.

Stolper, D. A., Revsbech, N. P., and Canfield, D. E. (2010). Aerobic growth at nanomolar oxygen concentrations. Proc. Natl. Acad. Sci. U. S.A. 107, 1875518760. doi: $10.1073 /$ pnas. 1013435107

Strous, M., and Jetten, M. S. M. (2004). Anaerobic oxidation of methane and ammonium. Annu. Rev. Microbiol. 58, 99-117. doi: 10.1146/annurev.micro.58. 030603.123605

Suominen, S., Dombrowski, N., Sinninghe Damsté, J. S., and Villanueva, L. (2019). A diverse uncultivated microbial community is responsible for organic matter degradation in the Black Sea sulfidic zone. Environ. Microbiol. doi: 10.1111/ 1462-2920.14902 [Online ahead of print]

Suzuki, D., Li, Z., Cui, X., Zhang, C., and Katayama, A. (2014). Reclassification of Desulfobacterium aniline as Desulfatiglans aniline comb. nov. within Desulfatiglans gen. nov., and description of a 4-chlorophenol-degrading sulfatereducing bacterium, Desulfatiglans parachlorophenolica sp. nov. Int. J. Syst. Evol. Microbiol. 64, 3081-3086. doi: 10.1099/ijs.0.064360-0

Tavormina, P. L., Hatzenpichler, R., McGlynn, S., Chadwick, G., Dawson, K. S., Connon, S. A., et al. (2015). Methyloprofundus sedimenti gen. nov., sp. nov., an obligate methanotroph from ocean sediment belonging to the 'deep sea1' clade of marine methanotrophs. Int. J. Syst. Evol. Microbiol. 65, 251-259. doi: $10.1099 /$ ijs. $0.062927-0$
Van Hove, P., Vincent, W. F., Galand, P. E., and Wilmotte, A. (2008). Abundance and diversity of picocyanobacteria in High Arctic lakes and fjords. Algol. Stud. 126, 209-227. doi: 10.1127/1864-1318/2008/0126-0209

Velinsky, D. J., and Fogel, M. L. (1999). Cycling of dissolved and particulate nitrogen and carbon in the Framvaren Fjord, Norway: stable isotopic variations. Mar. Chem. 67, 161-180. doi: 10.1016/s0304-4203(99)00057-2

Vetriani, C., Tran, H. V., and Kerkhof, L. J. (2003). Fingerprinting, microbial assemblages from the oxic/anoxic chemocline of the Black Sea. Appl. Environ. Microbiol. 69, 6481-6488. doi: 10.1128/aem.69.11.6481-6488.2003

Vetrov, A. A., Ponyaev, M. S., Belyaev, N. A., and Romankevich, E. A. (2015). Particulate organic matter along the Northern Sea Route. Oceanology 55, 347-354. doi: 10.1134/S0001437015030170

Vila, X., Abella, C. A., Figueras, J. B., and Hurley, J. P. (1998). Vertical models of phototrophic bacterial distribution in the metalimnetic microbial communities of several freshwater North-American kettle lakes. FEMS Microbiol. Ecol. 25, 287-299. doi: 10.1111/j.1574-6941.1998.tb00481.x

Walter, X. A., Picazo, A., Miracle, M. R., Vicente, E., Camacho, A., Aragno, M., et al. (2014). Phototrophic Fe (II)-oxidation in the chemocline of a ferruginous meromictic lake. Front. Microbiol. 5:713. doi: 10.3389/fmicb.2014.00713

Wand, U., Samarkin, V. A., Nitzsche, H.-M., and Hubberten, H.-W. (2006). Biogeochemistry of methane in the permanently ice-covered Lake Untersee, central Dronning Maud Land, East Antarctica. Limnol. Oceanogr. 51, 11801194. doi: $10.4319 /$ lo.2006.51.2.1180

Wang, Y. F., and Van Cappellen, P. (1996). A multicomponent reactive transport model of early diagenesis: application to redox cycling in coastal marine sediments. Geochim. Cosmochim. Acta 60, 2993-3014. doi: 10.1016/00167037(96)00140-8

Wartiainen, I., Hestnes, A. G., McDonald, I. R., and Svenning, M. M. (2006). Methylobacter tundripaludum sp. nov., a methane-oxidizing bacterium from Arctic wetland soil on the Svalbard islands, Norway (78 degrees N). Int. J. Syst. Evol. Microbiol. 56, 109-113. doi: 10.1099/ijs.0.63728-0

$\mathrm{Yu}, \mathrm{Y}$., Lee, C., Kim, J., and Hwang, S. (2005). Group-specific primer and probe sets to detect methanogenic communities using quantitative real-time polymerase chain reaction. Biotechnol. Bioeng. 89, 670-679. doi: 10.1002/bit.20347

Zadereev, E. S., Gulati, R. D., Camacho, A., Gulatei, R. D., Zadereev, E. S., and Degermendzhi, A. G. (eds) (2017). "Biological and ecological features, trophic structure and energy flow in meromictic lakes," in Ecology of Meromictic Lakes. Ecological Studies (Analysis and Synthesis), eds G. D. Ramesh, Zadereev, S. Egor, Degermendzhi, and G. Andrei (Cham: Springer), 61-86. doi: 10.1007/978-3319-49143-1_4

Conflict of Interest: The authors declare that the research was conducted in the absence of any commercial or financial relationships that could be construed as a potential conflict of interest.

Copyright (C) 2020 Savvichev, Kadnikov, Rusanov, Beletsky, Krasnova, Voronov, Kallistova, Veslopolova, Zakharova, Kokryatskaya, Losyuk, Demidenko, Belyaev, Sigalevich, Mardanov, Ravin and Pimenov. This is an open-access article distributed under the terms of the Creative Commons Attribution License (CC BY). The use, distribution or reproduction in other forums is permitted, provided the original author(s) and the copyright owner(s) are credited and that the original publication in this journal is cited, in accordance with accepted academic practice. No use, distribution or reproduction is permitted which does not comply with these terms. 